\title{
Induction Heater Based Battery Thermal Management System for Electric Vehicles ${ }^{\dagger}$
}

\author{
Waseem Raza ${ }^{1}$ (D), Gwang Soo Ko ${ }^{1}$ and Youn Cheol Park ${ }^{2, *}$ \\ 1 Graduate School of Mechanical Engineering, Jeju National University, Jeju 63243, Korea; \\ waseemraza7214@gmail.com (W.R.); gongvi1@msn.com (G.S.K.) \\ 2 Department of Mechanical Engineering, Jeju National University, Jeju 63243, Korea \\ * Correspondence: ycpark@jejunu.ac.kr \\ † Current address: HVACR Lab, Department of Mechanical Engineering, Jeju National University, \\ Jeju 63243, Korea.
}

Received: 1 September 2020; Accepted: 28 October 2020; Published: 31 October 2020

\begin{abstract}
The life and efficiency of electric vehicle batteries are susceptible to temperature. The impact of cold climate dramatically decreases battery life, while at the same time increasing internal impedance. Thus, a battery thermal management system (BTMS) is vital to heat and maintain temperature range if the electric vehicle's batteries are operating in a cold climate. This paper presents an induction heater-based battery thermal management system that aims to ensure thermal safety and prolong the life cycle of Lithium-ion batteries (Li-Bs). This study used a standard simulation tool known as GT-Suite to simulate the behavior of the proposed BTMS. For the heat transfer, an indirect liquid heating method with variations in flow rate was considered between Lithium-ion batteries. The battery and cabin heating rate was analyzed using the induction heater powers of 2, 4, and $6 \mathrm{~kW}$ at ambient temperatures of $-20,-10$, and $0{ }^{\circ} \mathrm{C}$. A water and ethylene glycol mixture with a ratio of 50:50 was considered as an operating fluid. The findings reveal that the thermal performance of the proposed system is generally increased by increasing the flow rate and affected by the induction heater capacity. It is evident that at $-20^{\circ} \mathrm{C}$ with $27 \mathrm{LPM}$ and $6 \mathrm{~kW}$ heater capacity, the maximum heat transfer rate is $0.0661^{\circ} \mathrm{C} / \mathrm{s}$, whereas the lowest is $0.0295^{\circ} \mathrm{C} / \mathrm{s}$ with $2 \mathrm{~kW}$ heater capacity. Furthermore, the proposed BTMS could be a practical approach and help to design the thermal system for electric vehicles in the future.
\end{abstract}

Keywords: battery; electric vehicle; thermal comfort; induction heater; energy management; heating

\section{Introduction}

Energy resources are increasingly important with rapid economic and social development, particularly in the transportation industry. The worldwide requirement for energy is projected to rise by almost a third until 2040, while oil may continue to rule the transport market [1]. Therefore, as an alternative to conventional fossil fuel vehicles, battery-powered electric vehicles (BEVs) have been a crucial resource to cope with climate change and create an environmentally-friendly sustainable transport system [2,3]. The underlying problems for EVs include the quest for a competent device for energy storage which can sustain long-distance, rapid charging, and high quality driving [4]. Li-ion battery-based EVs have remarkable benefits such as zero-emission, long-term longevity, and lower noise [5]. EV manufacturers have extensively used Lithium-ion batteries due to its substantial advantages such as high capacity, power efficiency, long life, and climate friendliness $[6,7]$. Recent developments in lithium-ion batteries (Li-Bs) have led to consideration as one of the most productive technologies for energy storage [8]. 
As one of the core components of EVs, driving range, speed, and acceleration heavily rely on the effectiveness of the battery. However, Li-ion batteries are highly confidential to harsh circumstances, for example, high temperature, over-charge, over-discharge, a short circuit, and crashing. In terms of Li-ion batteries, there are two major temperature concerns: the maximum temperature and the minimum temperature. Regarding the thermal management of $\mathrm{Li}-\mathrm{Bs}$, there is a lot of work carried out to enhance the safety of the battery. The working temperature for lithium-ion batteries should be in the range of $20-40{ }^{\circ} \mathrm{C}$ and module to module would not exceed $5^{\circ} \mathrm{C}$ in operating temperature difference [9-12]. Table 1 presents a review of the battery temperature range. Zhang et al. [13] found that, when the battery temperature drops below $20^{\circ} \mathrm{C}$, internal resistance ascends, and its performance decreases due to increased electrolyte viscosity. The discharge capacity declines dramatically to $78.6 \%$ of the usual operational conditions below the temperature of $-20^{\circ} \mathrm{C}$ [14].

Table 1. Advised operating temperature range for Li-Bs.

\begin{tabular}{lcl}
\hline References & Optimal Temperature Range ${ }^{\circ} \mathbf{C}$ & Type \\
\hline Pesaran et al. [11] & $15-35$ & Lithium-ion \\
Ladrech [15] & $20-30$ & Li-ion \\
Pesaran [16] & $25-40$ & Li-ion, lead-acid, NiMH \\
Sato [17] & $<50$ & Lithium-ion \\
\hline
\end{tabular}

Operating a lithium-ion battery at the temperature above their optimal temperature ranges can cause thermal runaway in the battery, resulting in a fire or an explosion [18], which has a severe effect on EVs' reliability and health. Each degree of temperature increase reduced the lifespan of lithium-ion batteries that run between 30 and $40{ }^{\circ} \mathrm{C}$ by two months [19]. Ramadass et al. tested the efficiency of Li-Bs under high operating temperatures, primarily on the Sony 18,650 battery. In addition, they found that running the battery with a temperature above the optimal for the same number of cycles leads to increased loss of battery capacity. When two batteries are run at 25 and $50{ }^{\circ} \mathrm{C}$, and operated for 300 cycles, a $50{ }^{\circ} \mathrm{C}$ running temperature battery would lose twice as much capacity as the one operating at $25^{\circ} \mathrm{C}$. For instance, while battery-operated at 50 versus $25^{\circ} \mathrm{C}$, the battery capacity losses increase for 300 cycles by more than $100 \%$ [20].

On the other hand, operating a battery at a temperature below their optimal temperature ranges can cause battery performance reduction, which limits their use in a cold climate. Low temperatures can affect batteries in a variety of ways, including charging receiving [21], round-trip efficiency [22], cost, and life span [23]. Friesen et al. [24] identified that the battery dendrites lithium from the battery anode, leading to a rapid decrease in battery safety if the lithium-ion battery runs at the lower ambient temperature over a long-term, and a high specific surface area. Lithium plating is another common result that occurs at the temperature below the optimum. Smart et al. [25] charged Li-ion cells at temperatures below their optimal and depicted that it is difficult to charge the battery to full capability, because lithium plating may happen at high charging levels at room temperature. The charge-transfer resistance of lithium iron phosphate batteries at $-20^{\circ} \mathrm{C}$ is stated to be three times higher than at room temperature [26].

Jung et al. [27] measured that, whereas the charge is the same, the usable capacity of Li-ion cell at the ambient temperature of $-20^{\circ} \mathrm{C}$ is just around $60 \%$ of room temperature mean value. In addition to this, the aging rate of $\mathrm{Li}$-Bs accelerated at low temperatures, particularly below $0{ }^{\circ} \mathrm{C}$ during cycling conditions. Lin et al., identified that, when the temperature reaches subzero, particularly below $-20{ }^{\circ} \mathrm{C}$, battery energy and capacity are greatly decreased [28]. The authors of $[13,29]$ found that the strength and density of Panasonic $18,650 \mathrm{Li}$-Bs at $25^{\circ} \mathrm{C}$ were $800 \mathrm{Wh} / \mathrm{L}, 100 \mathrm{Wh} / \mathrm{L}$, and $5 \mathrm{Wh} / \mathrm{L}$, which decreased by $98.75 \%$ and $95 \%$ to $<10 \mathrm{~W} / \mathrm{L}$ at $-40{ }^{\circ} \mathrm{C}$. The authors of $[30,31]$ observed that, at a temperature of $-10{ }^{\circ} \mathrm{C}, 11.5 \mathrm{Ah} \mathrm{Li}$-ion cells have power damage of $25 \%$ at a $0.5{ }^{\circ} \mathrm{C}$ rate of charge after cycling only 40 times. That may be much worse if hundreds of cells are connected in parallel or series. 
Thermal constancy is a significant concern for Li-ion battery packs. For the control of large temperature fluctuations and non-uniform thermal changes in the battery pack, to prolong the life cycle and take full advantage of power cell capability, a BTMS design has significant consequences [32]. The most crucial role of BTMS is to retain an acceptable running temperature range and constant distribution inside the battery cell, component, and packing at full charging/discharge rates and extreme outside climate conditions [33]. The BTMS should have features such as compactness, weightlessness, low price, high dependability, simple repairs, low use of power, and comfortable padding $[34,35]$. It should also be responsive to rapid heating and cooling. The BTMS aims to be capable of operating safe, sound, and effective in the confined space available in a modern vehicle, delivering the required heat transfer, and being able to produce on the economic front. Significant work has been conducted to establish an advanced BTMS that may be classified as various types. In addition to cooling and heating [10], internal and external [36], active and passive [34], series and parallel [37], phase change material (PCM), air, heat pipe (HP) and liquid [38], another method is the hybrid approach joining multiple techniques to satisfy the above-described conditions.

Many methods and connection management techniques for battery heating have been applied in previous works, including those based on forced air, liquids, heat pipe, and phase change materials [38]. However, most studies have shown that heat dissipation cannot be dramatically reduced through natural or forced air convection, mainly in extensive batteries [33]. Huo and Rao found that increasing PCM latent heat lowers the battery uniformity, which declines the lifespan of a battery [39]. A feasible and practical solution is needed to boost the performance of the BTMS. Consequently, with respect to the above-mentioned heating systems for EVs, liquid heating is more suitable for battery thermal management. It is more effective to provide a maximum heat transfer rate for heating and cooling function, and a lower amount of pumping power is required because of the enormous coefficient of heat transfer. An optimum temperature range for the battery pack may be attained either by a mini channel; with a jacket around a module; discrete tubing around each module; or by putting the pack on a liquid heated plate. Liquid heating is often weighed in terms of temperature drop, temperature distribution, and efficiency. Zhang et al. [40] found the heating rate $0.0057^{\circ} \mathrm{C} / \mathrm{s}$ by using the PTC heater with supplying $220 \mathrm{~V}$ AC power. In the proposed system, the maximum heating rate in $0.0679^{\circ} \mathrm{C} / \mathrm{s}$ by using the induction heater with a power of $6 \mathrm{~kW}$.

$\mathrm{Wu}$ et al. [41] reviewed the liquid-based battery thermal management systems and demonstrated that the BTMS coupled with other subsystems (e.g., HVAC) has tremendous potential for energy saving and efficiency promotion through the use of liquid circulation in vehicle thermal management. Ji et al. [42] tested a variety of standard heating methods with respect to energy consumption, method cost, heating efficiency, and heating time. For a battery pack made up of 16 lithium-ion prismatic cells with a power of $37 \mathrm{Ah}$. Luo et al. [43] developed a liquid heating system. Zhang et al. stated that higher amplitude, lower frequency, and feasible thermal insulation are heating increase factors [44]. Zhu et al. [45] proposed an analysis in comparison by connecting three PTC heaters to a BEV's initial pile-based liquid heating system, which can be operated by the charging pile. They found that, when the outside temperature is lower, the optimum preheating required temperature is increased, but it decreases as the vehicle travel distance increases because, during this long-range vehicle operation, the battery will warm itself. Furthermore, liquid-based thermal system performance could be improved by changing the flow rate. The author of Ref. [46] showed that systems thermal efficiency is generally improved by increasing refrigerant flow rates. Besides, a pump is often vital for circulating the working fluid at the required mass flow rate [47]. Nevertheless, liquid heating is commercially utilized in electric vehicles where the liquid is electrically heated such as Chevrolet Volt. The BMW i3 and i8, Volkswagen Volt plug-in hybrid EVs, and Tesla Model 3 and the Model S utilized liquid-based BTMS [48,49].

This paper aims to evaluate the thermal performance of a liquid-based BTMS under cold weather conditions. Our focus is on the indirect induction heating technique and development of a heating system that can achieve low energy consumption, high efficiency, reliability, and low cost. In other 
words, the main focus is on battery thermal performance and to find optimal values to design the system. An induction heater with various capacities is considered to warm the working fluid and the variations in flow rate used to stabilize the battery temperature between the optimum range. The results show the increase in heat transfer rate with the rise in flow rate, which is also influenced by heater capacity. For instance, the heat transfer rate is maximum at $27 \mathrm{LPM}$ at an ambient temperature $0{ }^{\circ} \mathrm{C}$ with $6 \mathrm{~kW}$ heater capacity, while the lowest is 0.0295 with $2 \mathrm{~kW}$ heater capacity. A BTMS that tracks, controls, manages, and ensures the thermal behavior of the battery is employed. The literature, as mentioned above, pays more consideration to the battery thermal management system to study. The paper is organized as follows. Section 2 presents the modeling, simulation, and system description. Section 3 demonstrates the results and discussion. The battery heat transfer rate, cabin heat transfer rate, overall system efficiency, and conclusions are presented in Section 4.

\section{Modeling, Simulation, and System Description}

Modeling, simulation, and system descriptions are covered in this section. GT-Suite (the industryleading simulation tool with features and collections targeting at a variety of technologies of applications and industries) software was considered in this study. The working fluid transfers the heat inside pipes and flows separated to their surfaces, which is determined using a coefficient of heat transfer. The coefficient of heat transfer is considered at any point phase of the fluid velocity, thermo-physical characteristics, and the composition of the wall unevenness. The smooth pipes' coefficient of heat transfer is determined using Equation (1). For a Reynolds number less than 2000, a Nusselt number of 3.6 is used; then, the heat transfer coefficient is defined by Equation (2).

$$
\begin{gathered}
h_{g}=\frac{1}{2} C_{f} \rho U_{\mathrm{eff}} C_{p} \operatorname{Pr}^{\left(-\frac{2}{3}\right)} \\
h_{g}=\frac{N u \cdot k}{d}
\end{gathered}
$$

In the series system, where liquid follows the one predefined path, as shown in Figure 1. The induction heater is used to warm the liquid with the energy transferred from electric to heat until it gets into the heater core. Where heat is transferred to the passenger's cabin, the air is blown over the coil to get a high temperature and circulate into the passenger's cabin to deliver temperature higher than the outside temperature to drive safely. A three-way valve is used to direct the liquid. Then, the liquid is directed towards the flow channel surrounds the batteries from defined ways for the heat transfer. A flow pump is also used to pressurize the liquid "coolant" throughout the cycle.

In the parallel system, the liquid follows two predefined ways as opposed to the series system shown in Figure 2. The operating fluid follows two routes: one towards the battery pack and the other towards the heater core [50]. These are the two configurations extensively used in liquid heating or cooling systems in electric vehicles. In this study, the series configuration was utilized for battery thermal enhancement, i.e., to know the optimal solution or develop a thermal system for the battery. The details of the system components are described in the upcoming sections. The reason for choosing the liquid heating system is the heat transfer coefficient. The system using liquid has also been implemented in commercial EVs due to its high heating rate performance and compatibility. A liquid-based system can reduce energy consumption based on the performance feature of pressure drop, temperature drop, and homogeneity. 


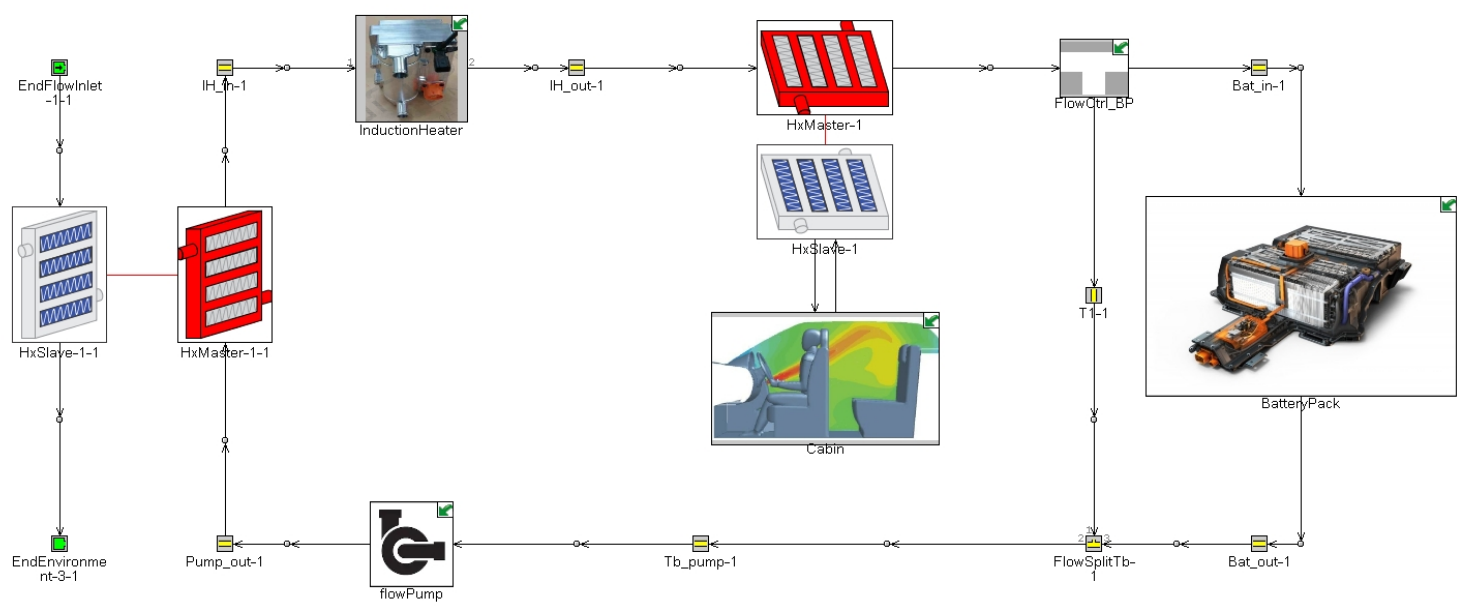

Figure 1. BTMS schematic diagram: series configuration.

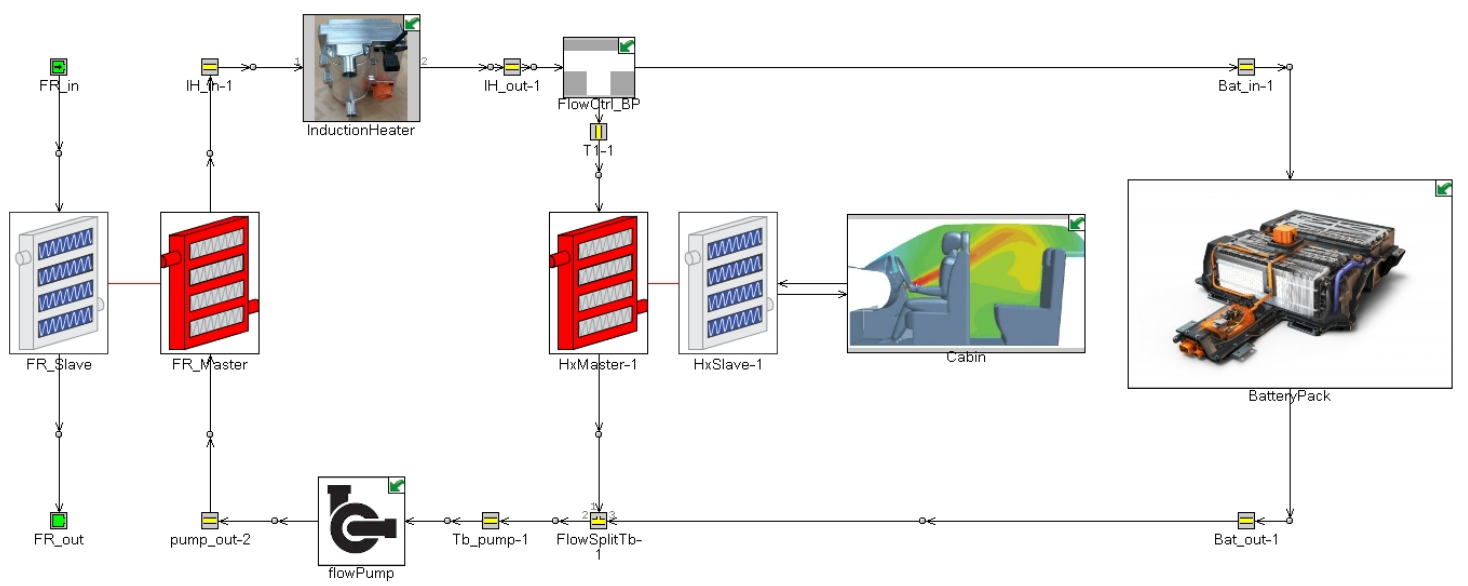

Figure 2. Schematic diagram of the battery thermal management system: parallel configuration.

\subsection{Induction Heater}

One of the core elements of the battery thermal management system is an induction heater in the electric vehicle. The electric vehicle needs an independent heat-generating device since no engine holds the battery temperature and powers the heat pump. Due to the characteristics of rapid temperature rise by direct input of electric power, the most satisfactory solution for a heat source is an induction heater. The heater generates heat directly from a Litz coil by electromagnetic forces in work-pieces prepared from ferromagnetic materials, through which high-frequency AC voltage is produced. The induction heater has high-performance characteristics, and extraordinary rapid temperature increase times up to the optimal temperature [51]. The induction heater is also semi-permanent due to the lack of consumable parts [52]. Another critical aspect of the heater induction mechanism is that the heat is generated internally, instead of by heat conduction from an external heat source, and the battery heats up very quickly. Whenever the coil moves into contact with the work-piece, the induction heater coils are destroyed by heat. Hence, the nonmagnetic material-based bobbin is placed between the work-piece and the coil. Figure 3 shows a simulation diagram for an induction heater. By adding the power supply, the heater can conveniently produce enough heat without any safety concern.

The reason behind choosing the induction heater for liquid heating is the efficiency of an induction heater as compared to the resistance heater. The US Department of Energy has estimated electric coil efficiency as about $74-77 \%$ and induction at $84 \%$. Moreover, induction heating prolongs the life of fixtures as the accurate heating provides rapid start-up to save time due to the absence of thermal inertia and makes the battery thermal system productive. Another factor involved in the 
selection is cost-effectiveness; a higher energy-saving rate is obtained if the power capacity is higher. Besides, heating by induction has a minimum loss of heat to the surroundings with direct transfer of energy to the liquid.

In contrast to the heat pump, an induction heater is sufficient in terms of energy-saving as thermal comfort, and battery thermal safety is an auxiliary load on the battery pack. Despite that, the heat pump system is more complex, and the upfront cost is more than the induction heater-based BTMS. Zhang et al. [53] found that the electric vehicle heat pump system reduced heating performance when working in cold weather conditions. Thus, full heat pump efficiency in cold weather cannot be reached.

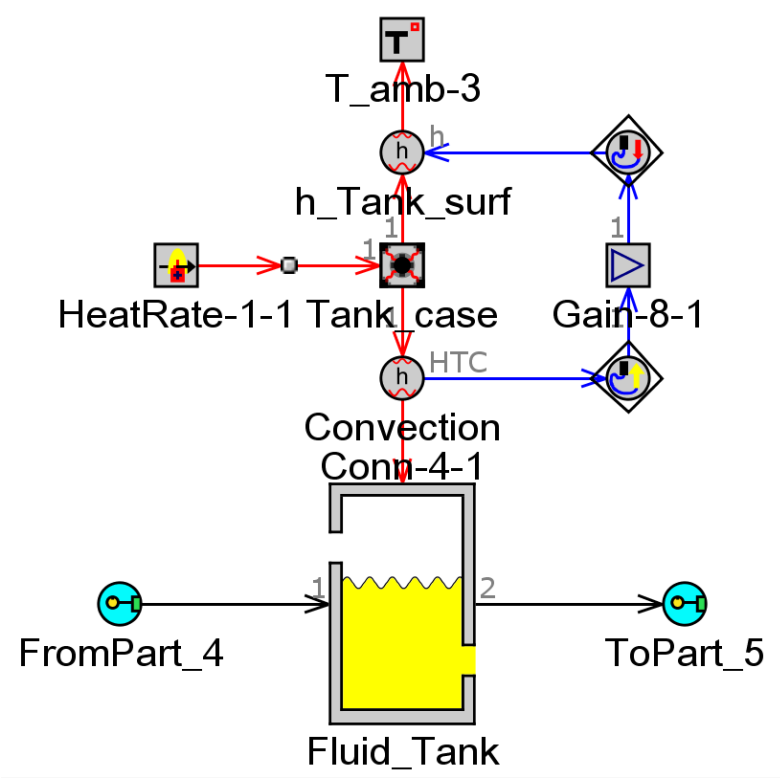

Figure 3. Induction heater modeling diagram.

\subsection{Lithium-ion Battery Pack}

The battery is the heart and an integral component of the EVs. A pouch-type lithium polymer cell with a cathode NCM 622 (Nickel Cobalt Manganese Oxide) and graphite anode is considered as a reference battery cell to ensure an optimum temperature range and a consistent temperature delivery within the battery pack. The battery pack sits under the floor of the vehicle, and a full pack consists of five modules. The process of cell to battery pack assembly is illustrated in Figure 4 . The battery cell size is $300 \mathrm{~mm} \times 98 \mathrm{~mm} \times 14 \mathrm{~mm}$, and the capacity is $60 \mathrm{Ah}$. Li-ion polymer rechargeable batteries manufactured by LG-Electronics were used to model the battery pack; all other necessary technical information of a Li-ion battery is presented in Table 2.

The aim is to keep the battery operating at an appropriate temperature. Figure 5 shows the battery pack modeling diagram considered in this study. Three types of battery heating methods are used: convective heating, self-internal heating, and mutual pulse heating [42]. The convective heating approach can heat the battery both inside and outside. The fan creates a convective flow, and a heater transforms electric power to heat the fluid. Song [54] added a heating resistor into the forced air BTMS and heating batteries with convective. The author of Ref. [55] compared two types of battery heating strategies: silicon plate heating and forced air convection heating. Besides, a liquid heating system because of its high efficiency is commonly practiced in EV manufacturing.

Furthermore, the liquid flow channel needs to be constructed correctly. The system's heat transfer capacity degrades, leaving the battery pack uneven in temperature distribution. In a liquid-based system with indirect-contact, the heat transfer fluid is conditioned using an induction heater and transported by a fixed heating circuit across the channels. Owing to the lower viscosity of the thermal fluid (ethylene glycol or water) than the dielectric fluids (e.g., mineral oil), the indirect form of liquid transmission is more practical to be implemented, resulting in a slightly higher fluid flow rate [56]. 
The thermophysical characteristics of the operating fluid are as follows: a specific heat capacity around $3323 \mathrm{~J} \cdot \mathrm{kg}^{-1} \cdot \mathrm{K}^{-1}$, density of $1069 \mathrm{~kg} \cdot \mathrm{m}^{-3}$, kinematic viscosity of $2.58 \times 10^{-6}$, and thermal conductivity of $0.3892 \mathrm{~W} \cdot \mathrm{m}^{-1} \cdot \mathrm{K}^{-1}$.

The working fluid has an indirect connection with the battery and warms the liquid "coolant" just before it enters into the pack. The working fluid circulated through the flow channel between the batteries and transferred the heat to the batteries inside the battery pack. The flow channel surrounding the battery was tightly arranged of pipes and covered the pack from all directions. The dimensions of the flow pattern are as follows: pipe diameter of around $10.6 \mathrm{~mm}$, overall width from the entrance of the operating fluid to the outlet of about $5000 \mathrm{~mm}$, and the gap between two consecutive pipes of almost $10 \mathrm{~mm}$. The working fluid needs to be powered by the applicable device. A pump is installed along with the liquid circulation. The lowest and highest flow rates were 3 and 27 LPM, respectively. Meanwhile, the increasing flow rate of cooling liquid caused the energy consumption of the pump to increase dramatically because the pack itself mainly supplies the battery energy consumption for the heating system.

Table 2. Technical specification of a Li-ion battery.

\begin{tabular}{lcc}
\hline Parameter & Unit & Value \\
\hline Model No. & - & LG60AH-3.6 V/60 Ah \\
Capacity & $\mathrm{Ah}$ & 60 \\
Voltage & $\mathrm{V}$ & 3.65 \\
Width & $\mathrm{mm}$ & 98 \\
Length & $\mathrm{mm}$ & 300 \\
Thickness & $\mathrm{mm}$ & 14 \\
Discharge cut-off voltage & $\mathrm{V}$ & 2.75 \\
Capacitance C1 & $\mathrm{kF}$ & 40 \\
Resistance R0 & $\mathrm{m}$ & 5.5 \\
Internal resistance R0 & $\mathrm{m}$ & 13 \\
Charge cut-off voltage & $\mathrm{V}$ & 4.2 \\
Standard current & $\mathrm{C}$ & $0.5(30 \mathrm{~A})$ \\
Maximum Charging current & $\mathrm{C}$ & $1(60 \mathrm{~A})$ \\
Maximum discharging current & $\mathrm{C}$ & $3(180 \mathrm{~A})$ \\
\hline
\end{tabular}

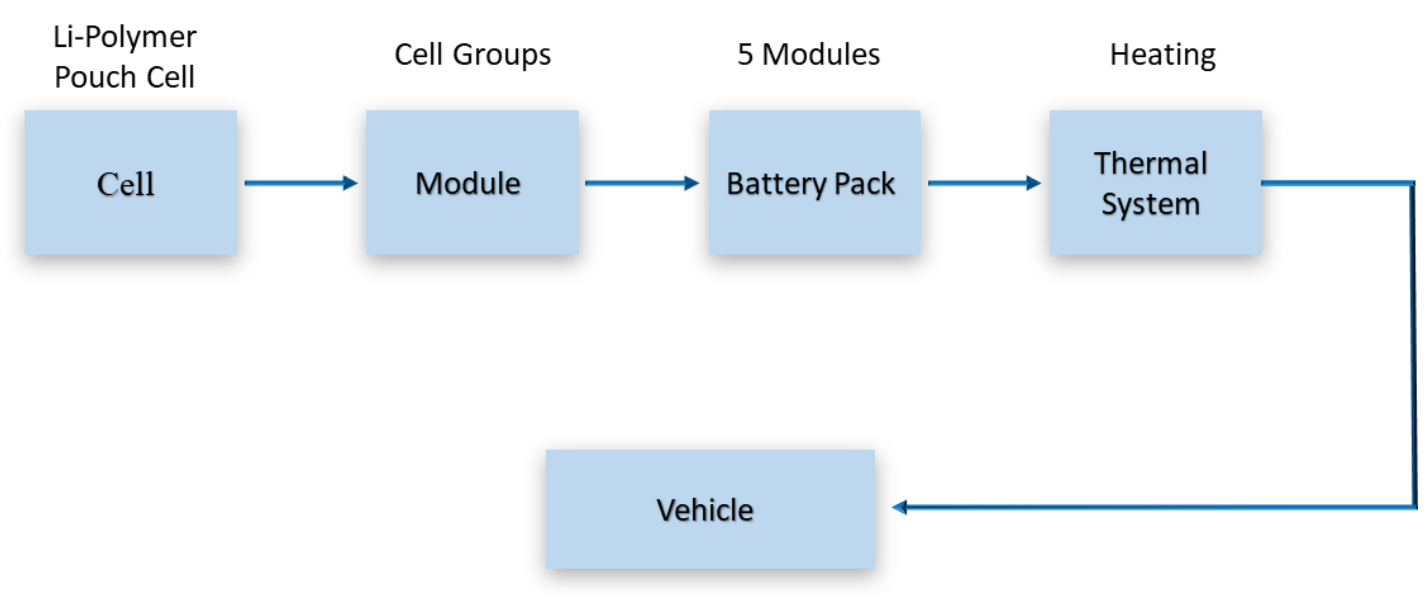

Figure 4. The process of cell to a battery pack assembly. 


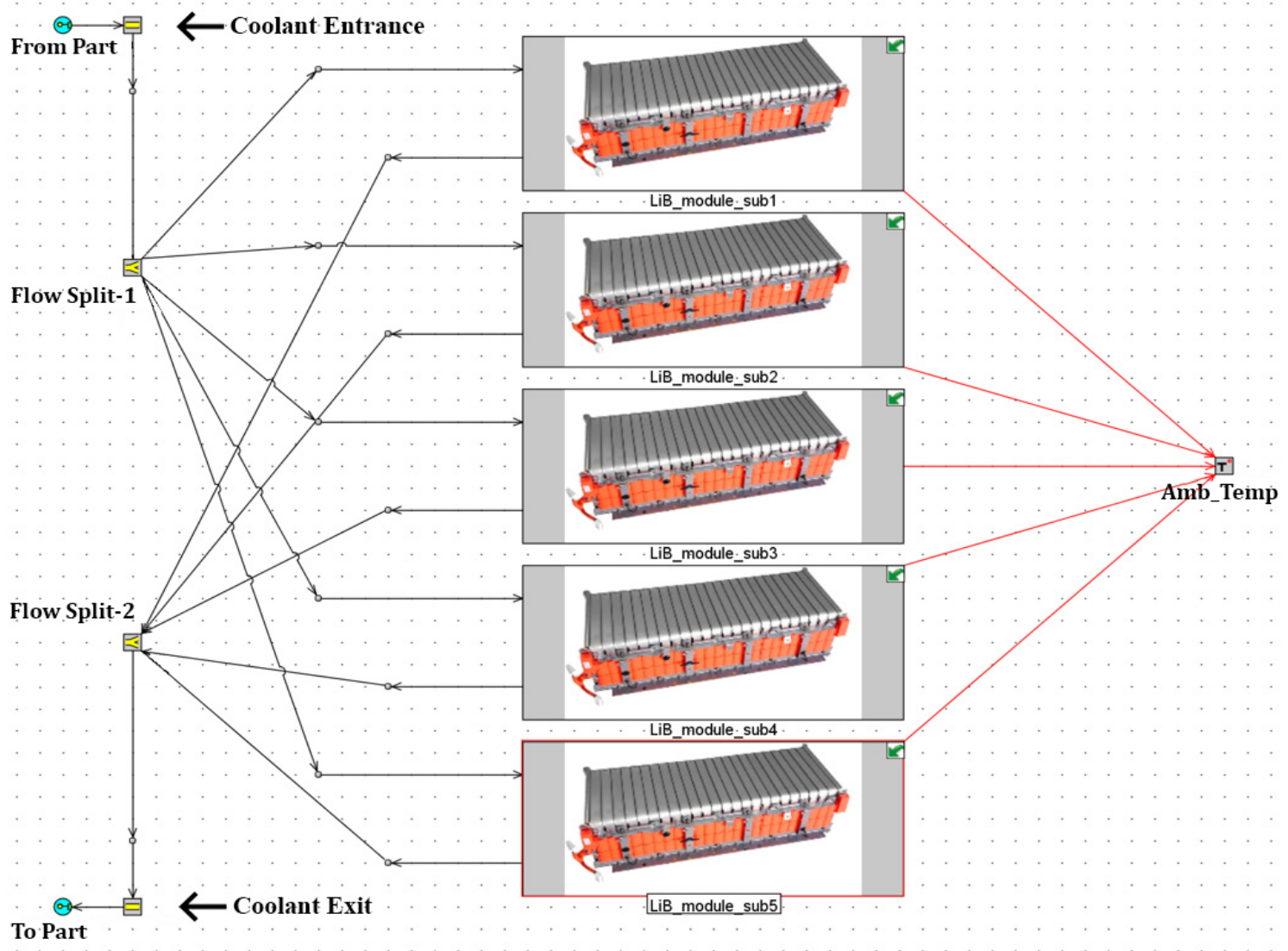

Figure 5. A battery pack modeling diagram.

\subsection{Cabin}

Air conditioning is one of the leading automobile systems used to preserve the inside comfort, including temperature, humidity, and air velocity. In the case of an electric vehicle, there is no engine to drive this kind of system. The same working fluid used for battery heating is used in a heater core to provide hot air inside the cabin for the passenger's comfort. A prominent factor in driving protection is also how thermally stable the cabin situation is for the driver [57]. In one study, car drivers missed 50\% of test signals at $27^{\circ} \mathrm{C}$, the reaction time being $22 \%$ lower than at $21^{\circ} \mathrm{C}$ due to thermal discomfort [58]. Therefore, thermal comfort is essential to provide heating in cold weather and cooling in hot and humid weather. In this analysis, heating was supplied by the air blow over the heater core at low ambient temperatures. A fan was used for air circulation. The design properties of the cabin are given in Table 3.

Another critical component of BTMS is the heater core. The heater core was considered inside the cabin to offer heat. The heater core conditions were an airflow rate of 200-400 CMH; working fluid flow rates of 3, 6, and $10 \mathrm{LPM}$; and supply water temperature of $85^{\circ} \mathrm{C}$. The heater core simulation diagram is demonstrated in Figure 6, while experimental and simulation data are shown in Figure 7, where air volume and flow rate data are plotted with the heater capacity.

\subsection{Experimental Conditions}

The heat transfer rate related to the flow rate of working fluid for the BTMS of an electric vehicle was investigated under cold climate situations based on the existing standard with heater power variations of 2,4 , and $6 \mathrm{~kW}$ and outside temperatures of $-20,-10$, and $0{ }^{\circ} \mathrm{C}$. Tables 4 and 5 display the experimental conditions for the cabin and battery pack. 


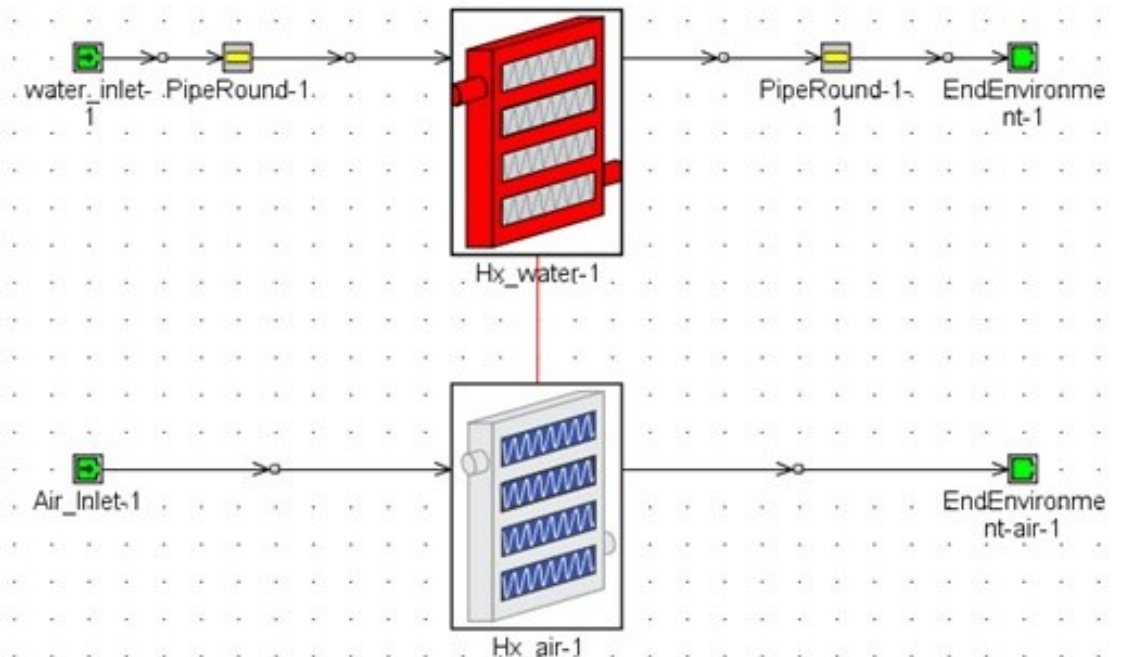

Figure 6. Heater core modeling diagram.

Table 3. Cabin properties.

\begin{tabular}{lc}
\hline Parameter & Value \\
\hline Cabin size & $2300 \mathrm{~mm} \times 1300 \mathrm{~mm} \times 1190 \mathrm{~mm}$ \\
Front window area & $0.858 \mathrm{~m}^{2}$ \\
Side window area & $1.0864 \mathrm{~m}^{2}$ \\
Rear window area & $0.6832 \mathrm{~m}^{2}$ \\
Solar load & $0.9,1.3 \mathrm{~kW} / \mathrm{m}^{2}$ \\
Human heat source & $120 \mathrm{~W}$ \\
\hline
\end{tabular}

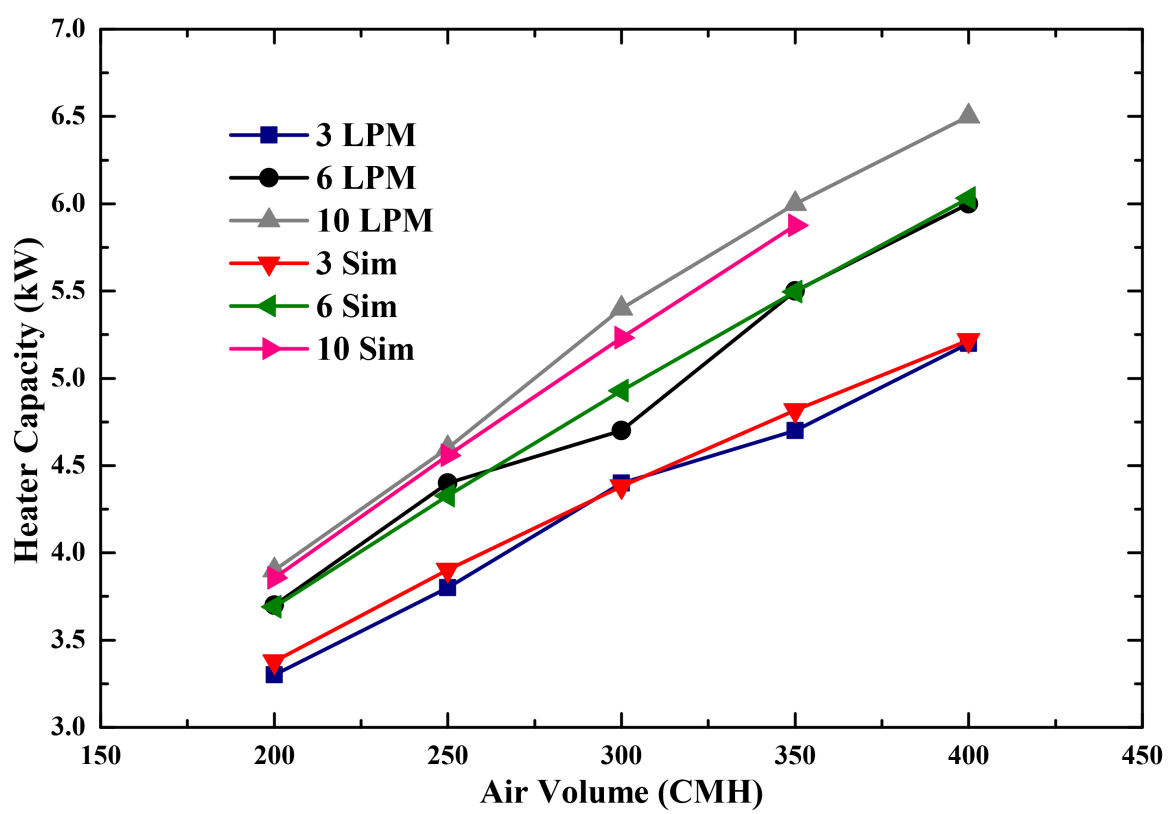

Figure 7. Heater core capacity with air volume. 
Table 4. The cabin experimental conditions.

\begin{tabular}{|c|c|c|c|}
\hline Ambient Temperature $\left({ }^{\circ} \mathrm{C}\right)$ & Target Temperature $\left({ }^{\circ} \mathrm{C}\right)$ & Passenger No. & Control Method $\left({ }^{\circ} \mathrm{C}\right)$ \\
\hline-20 & \multirow{3}{*}{25} & \multirow{3}{*}{$1 \sim 4$} & \multirow{3}{*}{0.5} \\
\hline-10 & & & \\
\hline 0 & & & \\
\hline
\end{tabular}

Table 5. Experimental conditions of a battery pack.

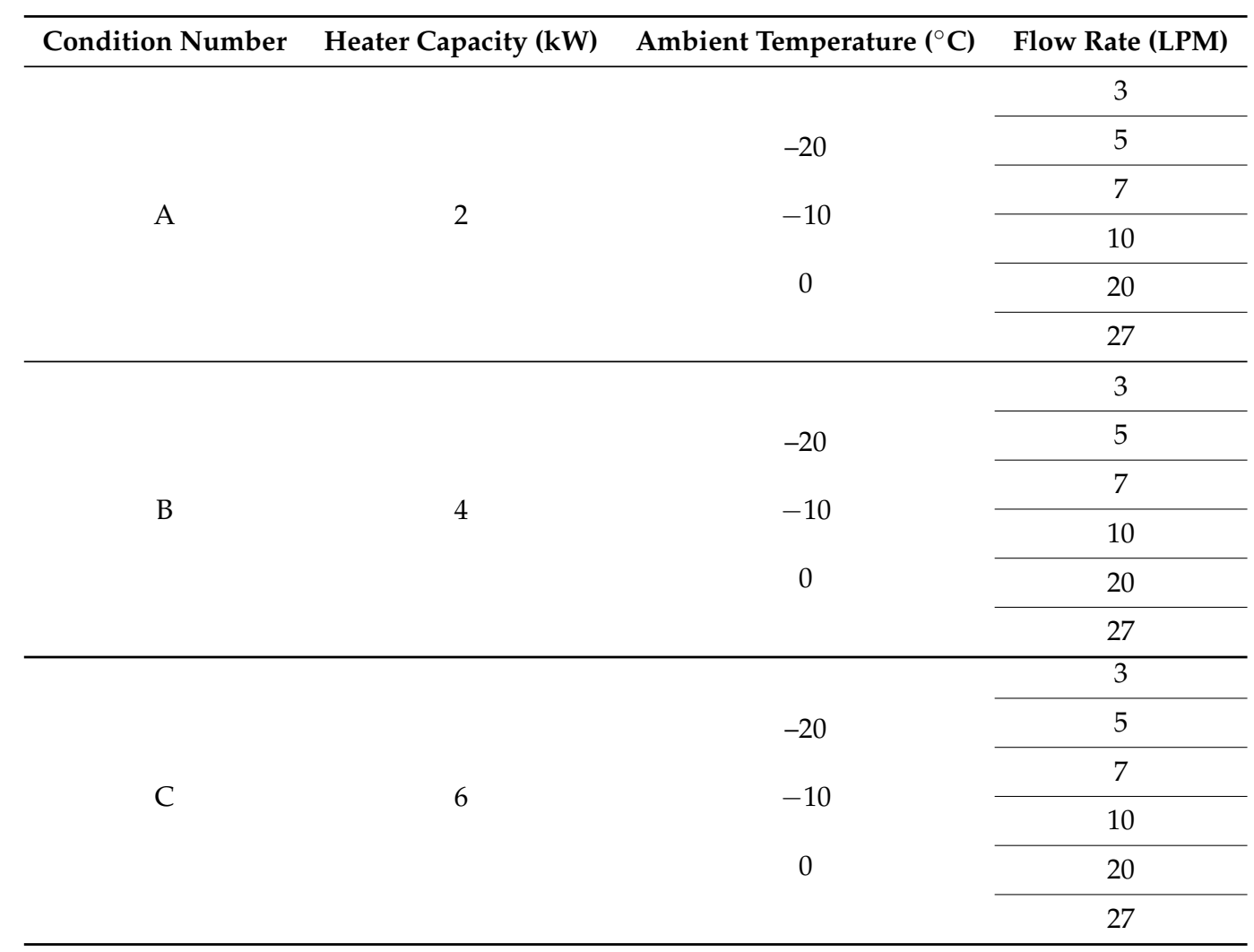

\section{Results and Discussion}

In this section, the battery thermal management system for the cabin and battery of an electric vehicle is examined with flow rate and induction heater powers under cold weather conditions. The flow rate and the capacity of the induction heater were varied as 3, 5, 7, 10, 20, and 27 LPM and 2, 4 , and $6 \mathrm{~kW}$, respectively. Additionally, system's outside temperatures were $0,-10$, and $-20{ }^{\circ} \mathrm{C}$.

\subsection{Battery Heat Transfer Rate}

Figure 8 illustrates the differences in the heat transfer rate vs. the flow rate of working fluid under the cold weather temperatures of $0,-10$, and $-20^{\circ} \mathrm{C}$ with $2 \mathrm{~kW}$ heater capacity, respectively, for the battery. As shown in Figure 8, there is a smooth increment in the pattern; the battery heating system has an improved heating rate with an increase in the working fluid flow rate. One can see that the heating rate at $10 \mathrm{LPM}$ is around $0.0271^{\circ} \mathrm{C} / \mathrm{s}$, while, at $27 \mathrm{LPM}$, it is $0.0291{ }^{\circ} \mathrm{C} / \mathrm{s}$ at ambient temperature $-10{ }^{\circ} \mathrm{C}$, which demonstrates the rise in the heating rate with the LPM. Owing to the high specific ability, the heat transfer rate of liquid fluid is higher. In addition, the induction heater capacity affects the increase in the heating rate. 


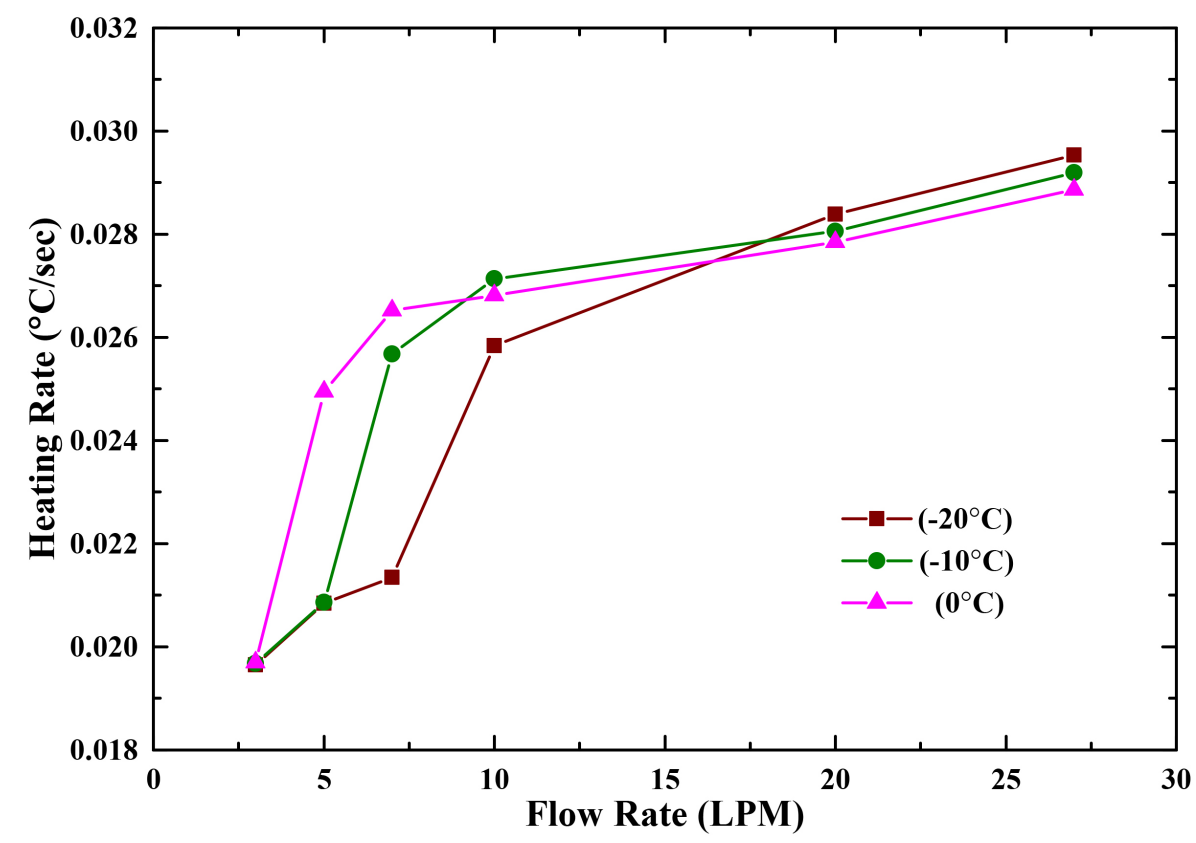

Figure 8. Heating rate as a function of flow rate with heater capacity: $2 \mathrm{~kW}$.

Figure 9 corresponds to the heating rate impact on the flow rate of working fluid with the battery heating power of $4 \mathrm{~kW}$ under cold weather temperatures $0,-10$, and $-20^{\circ} \mathrm{C}$, respectively. It depicts that the heating rate of the battery heating system increases towards the optimum flow rate; the heating rate is about $0.0366{ }^{\circ} \mathrm{C} / \mathrm{s}$ with $5 \mathrm{LPM}$. On the other hand, it is $0.0500{ }^{\circ} \mathrm{C} / \mathrm{s}$ with a flow rate of $20 \mathrm{LPM}$ and peaked at $0.0507{ }^{\circ} \mathrm{C} / \mathrm{s}$ with $27 \mathrm{LPM}$ at an outside temperature of $0{ }^{\circ} \mathrm{C}$. The induction heater capacity also increased from 2 to $4 \mathrm{~kW}$ in this case, which has a positive impact on the improvement of the heating rate. The figure shows the increase in the heating rate with the change in the rate of working fluid flow.

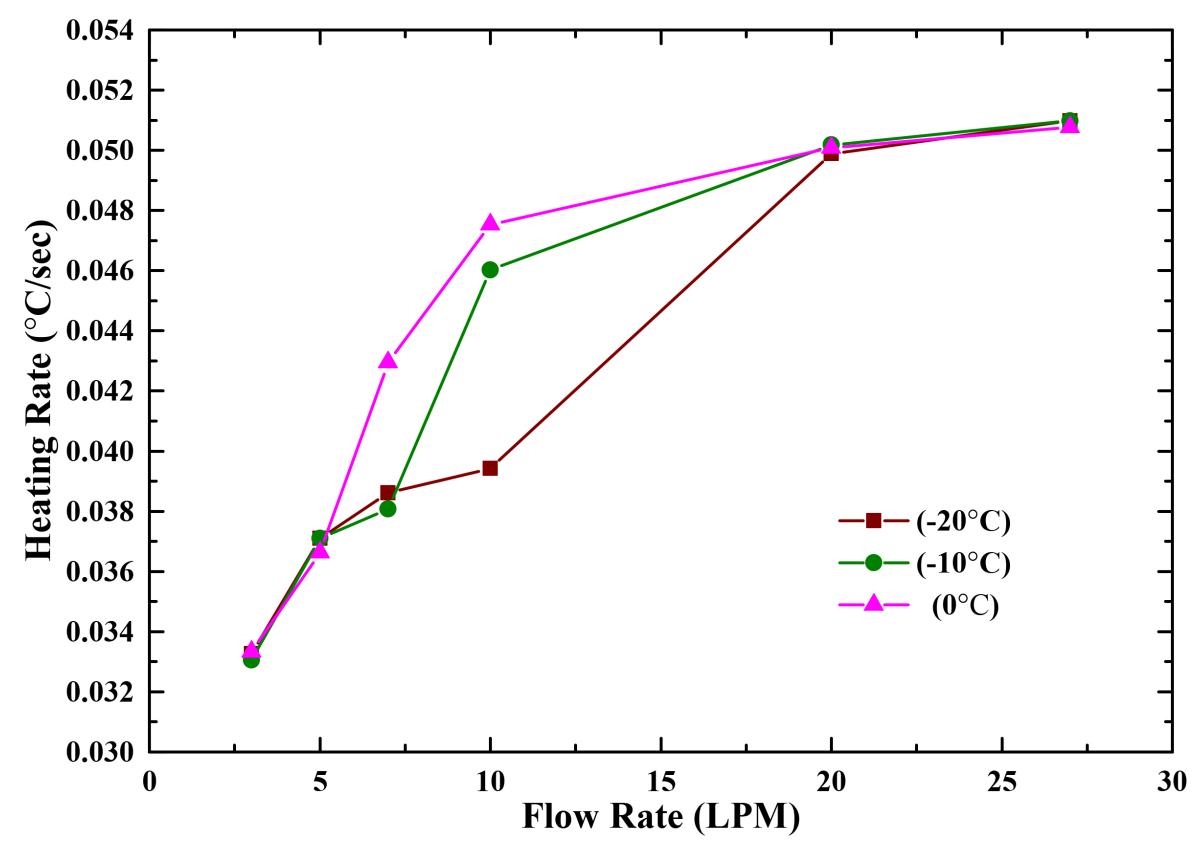

Figure 9. Heating rate as a function of flow rate with heater capacity: $4 \mathrm{~kW}$.

Figure 10 demonstrates the heating rate regarding the flow rate with $6 \mathrm{~kW}$ heater capacity at cold weather temperatures of $0,-10$, and $-20^{\circ} \mathrm{C}$, respectively, for the battery. The heating rate of 
all three ambient temperature conditions begins to rise over the same rate up to 10 LPM. After that, unusual changes in the pattern can be seen. The heating rate is approximately the same, with a minor difference at the flow rate of $27 \mathrm{LPM}$. The battery heating rate is also improved as the flow rate increases. The heating rate with $3 \mathrm{LPM}$ is almost $0.0331^{\circ} \mathrm{C} / \mathrm{s}$, and, with $27 \mathrm{LPM}$, it is $0.0661{ }^{\circ} \mathrm{C} / \mathrm{s}$, which is the maximum heat transfer rate at $-20^{\circ} \mathrm{C}$ outside temperature. In this condition, the induction heater capacity is the maximum of all the times, which also affected the rate of heat transfer.

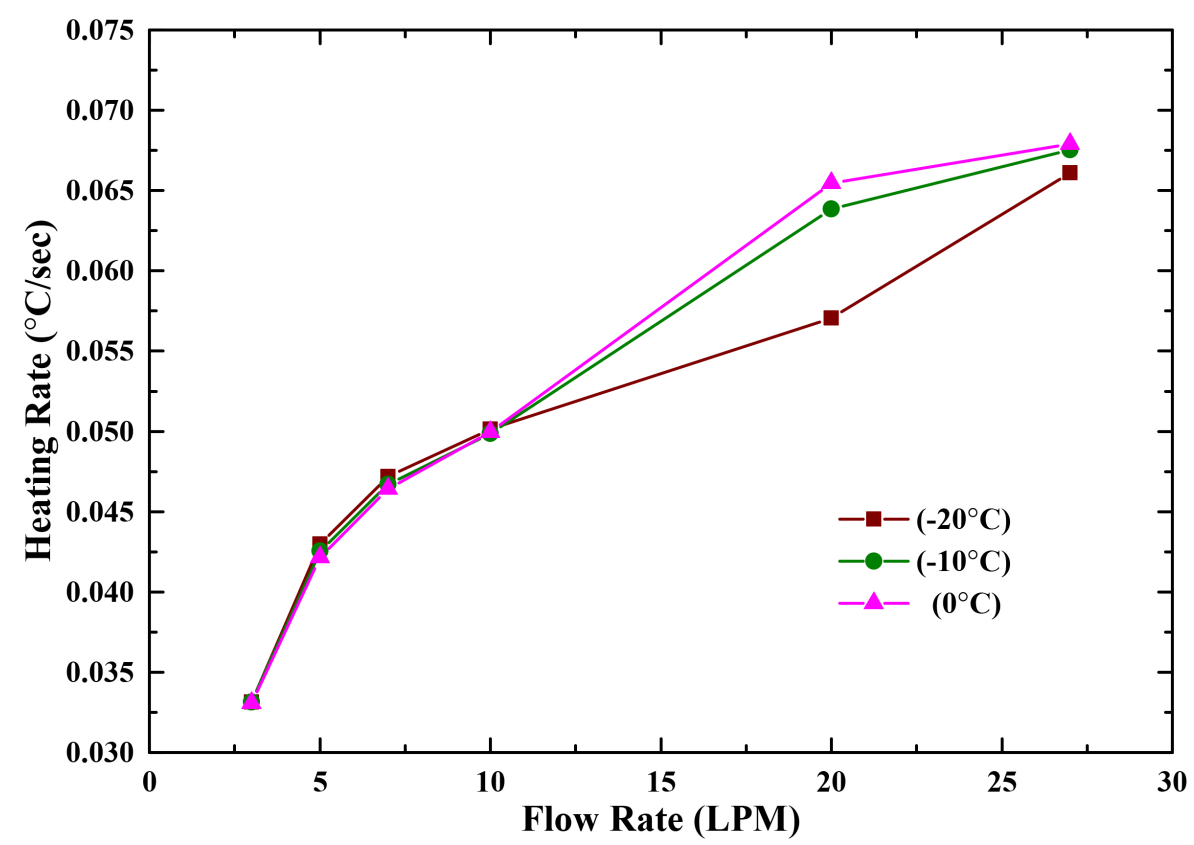

Figure 10. Heating rate as a function of flow rate with heater capacity: $6 \mathrm{~kW}$.

\subsection{Cabin Heat Transfer Rate}

The air condition system is essential to guarantee thermal comfort for drivers and passengers. Automobiles use the engine exhaust's gas waste heat for cabin heating with internal combustion engines. Despite that, EV needs separate equipment for heating since there is no exhaust gas for heating. The heater core employed heat for the cabin with the help of an induction heater. The hot air was blown into the cabin for heating. The effects of the cabin heat transfer rate are discussed in this part of the section experiment findings. The ambient temperatures considered for the experiments were $0,-10$, and $-20^{\circ} \mathrm{C}$. The induction heater capacity was 2,4 , and $6 \mathrm{~kW}$. The airflow considered for cabin heating was about $400 \mathrm{CMH}$.

Figure 11 presents the influence of the cabin heating rate in terms of the flow rate of the working fluid. Cabin heating is keen for safe driving and passenger comfort. The cabin heating rate is determined to check the performance of the system. Variations of the heating rate for flow rate under three different outside temperatures are illustrated. The airflow and the heater capacity considered for the experiment were $400 \mathrm{CMH}$ and $2 \mathrm{~kW}$, respectively. It can be observed that the heating rate is the maximum at $3 \mathrm{LPM}$, which is $0.0301{ }^{\circ} \mathrm{C} / \mathrm{s}$ at an outside temperature of $-20^{\circ} \mathrm{C}$. All variations of ambient temperatures represent the increase in the flow direction, causing the reduction in the heating rate up to 10 LPM; after that, there is an irregular pattern followed by 20 LPM. Once LPM hit all three variations at 20, it again depicts the increase in the heating rate that shows the flow rate effect on heat transfer.

Figure 12 demonstrates the effects of the cabin heating rate versus the flow rate of a working fluid. The cabin heating rate is investigated to find the thermal performance of the system. The airflow and the heater capacity considered for the experiment were $400 \mathrm{CMH}$ and $4 \mathrm{~kW}$, respectively. Variations of the heating rate under three different ambient temperatures to flow rate are illustrated in Figure 12. 
It can be observed that the heating rate is highest at $-20{ }^{\circ} \mathrm{C}$ ambient temperature with a flow rate of $3 \mathrm{LPM}$, which is $0.0563^{\circ} \mathrm{C} / \mathrm{s}$. All three variations of ambient temperatures show that the change in flow direction triggers a decrease in the heating rate followed by 20 LPM after the rise in heating rate level from 20 to 27 LPM, which indicates the effect of the change in flow rate.

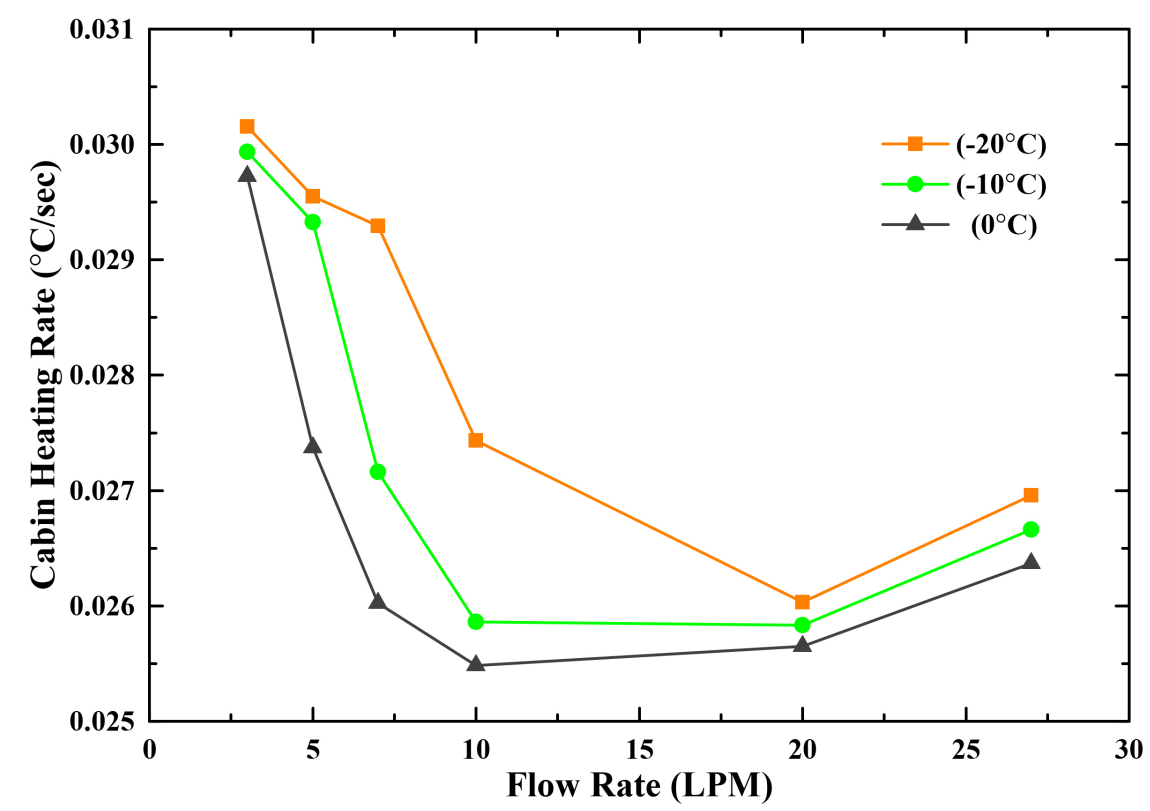

Figure 11. Cabin heating rate versus flow rate at $400 \mathrm{CMH}$ airflow and heater capacity: $2 \mathrm{~kW}$.

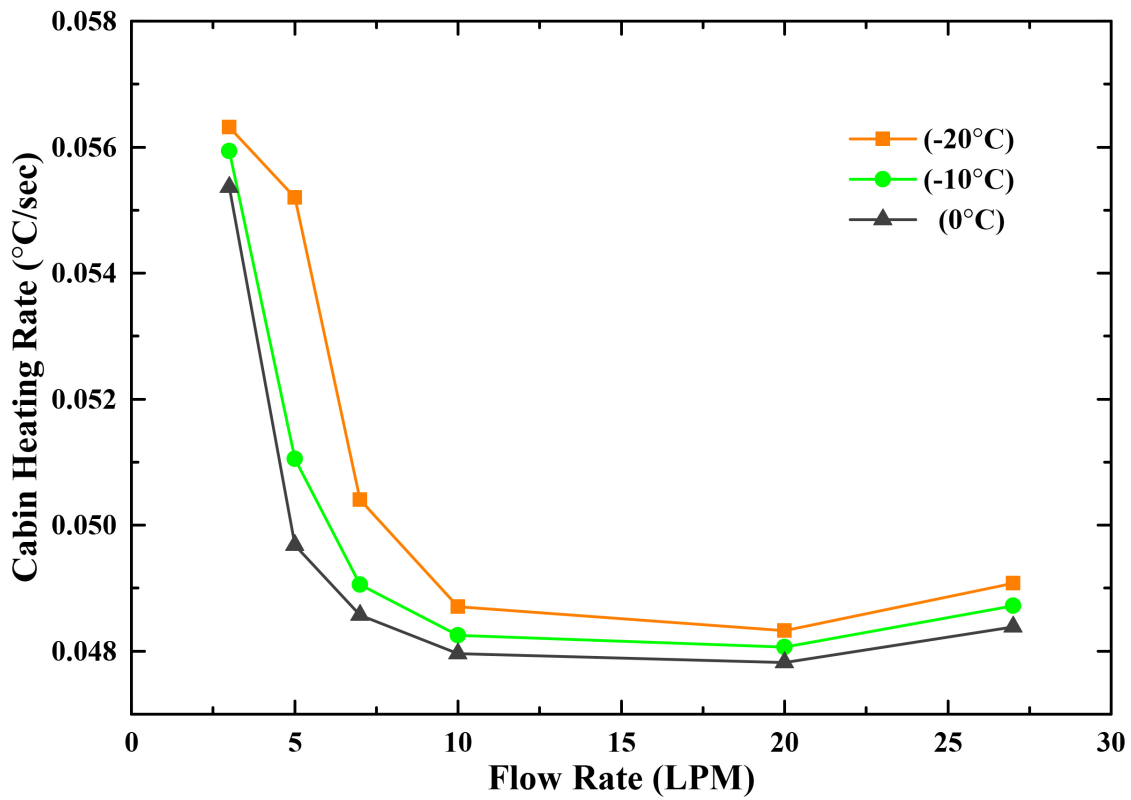

Figure 12. Cabin heating rate versus flow rate at $400 \mathrm{CMH}$ airflow and heater capacity: $4 \mathrm{~kW}$.

The cabin heating rate is measured to assess the performance. Figure 13 illustrates the effect of the cabin heating rate on the working fluid flow rate. The airflow and heater capacity considered for the experiment were $400 \mathrm{CMH}$ and $6 \mathrm{~kW}$, respectively. Variations of the heating rate concerning flow rate under various outside temperatures are shown in Figure 13. All three changes in ambient temperatures show that the change in flow direction reasons for the heating rate to decrease up to 20 LPM. When LPM reached all three variations at 20 , the rise in the heating rate, which directs the influence of flow rate rise again, is at the highest heating level at a flow rate of $3 \mathrm{LPM}$, which is $0.0790^{\circ} \mathrm{C} / \mathrm{s}$ at an outside 
temperature of $-20{ }^{\circ} \mathrm{C}$. In contrast, the minimum is approximately $0.06748^{\circ} \mathrm{C} / \mathrm{s}$ with the $20 \mathrm{LPM}$ flow rate at $0{ }^{\circ} \mathrm{C}$ ambient temperature.

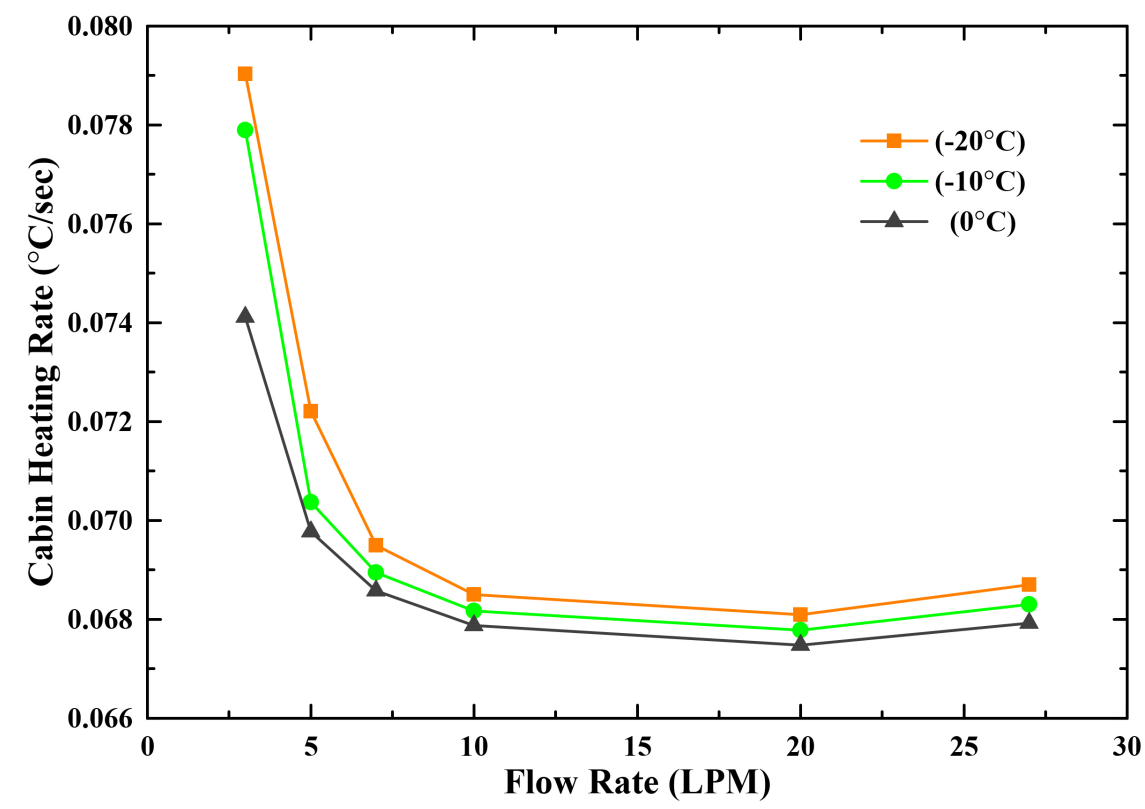

Figure 13. Cabin heating rate versus flow rate at $400 \mathrm{CMH}$ airflow and heater capacity: $6 \mathrm{~kW}$.

Figure 14 demonstrates the influence of power consumption on the working fluid flow rate. The consumption of pump power is critical for measuring the overall efficiency of the system. It can be seen that there is a linear increase in power consumption and minimum power consumption for the pump is about $32.5 \mathrm{~W}$ with $3 \mathrm{LPM}$ and nearly $43 \mathrm{~W}$ with $27 \mathrm{LPM}$. The values show that the change in fluid flow rate is responsible for the increase in power consumption. To find the systems optimum flow rate considering ambient temperature for each heater capacity and power consumption, Equation (3) is used, where $\dot{m}$ represents the mass flow rate.

$$
\dot{m}=5-0.15(\text { battery tem } p)+0.005(\text { battery tem } p)^{2}
$$

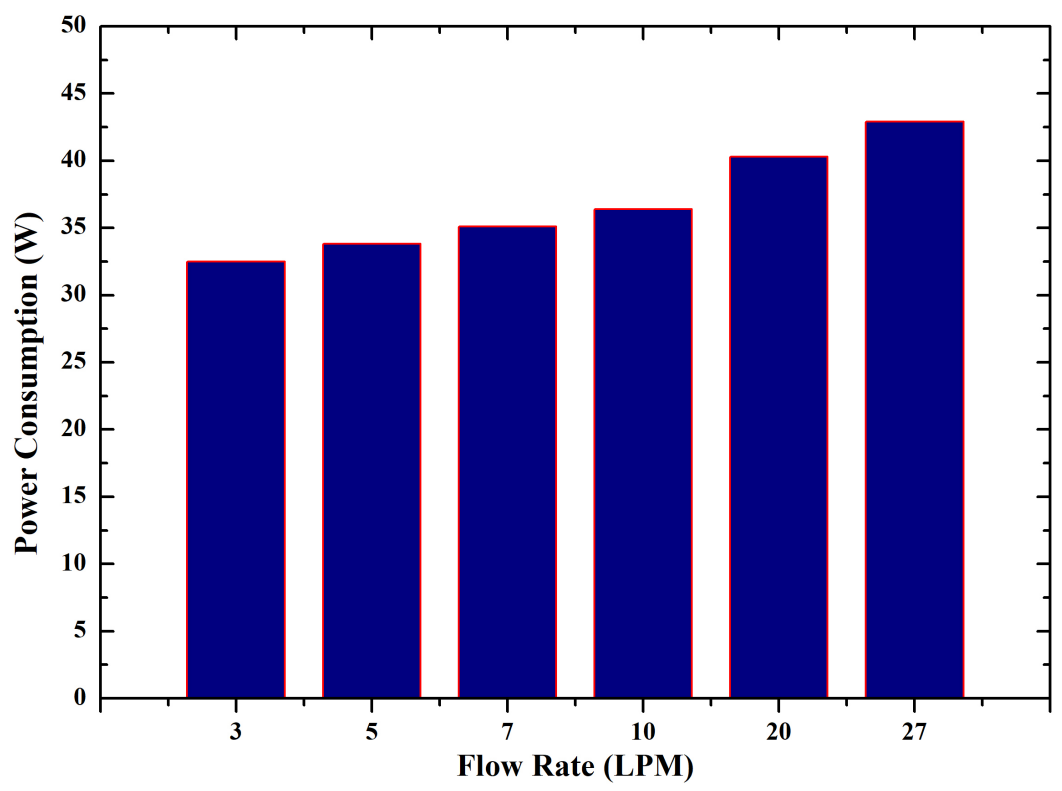

Figure 14. Pump power consumption against flow rate. 


\subsection{Overall System Efficiency}

Battery and cabin heat transfer rate are discussed above. In this section, we discuss the overall efficiency of an electric vehicle's battery and cabin heating system, including power consumption by the system during the operating cycle. Power consumption is also shown in Figure 14. The power consumption separates the heating rate of the battery and cabin in order to evaluate the systems' effectiveness and performance as a function of flow rate.

Firstly, Figure 15 presents the overall efficiency of the thermal management system in a series configuration to flow rate. The variations of three different ambient temperatures and the capacity of the induction heater considered for this experiment was $2 \mathrm{~kW}$. All variations in the ambient temperatures display the irregular pattern of increments and decrements. The data indicate that the efficiency with the low LPM is higher and is lower with the maximum flow rate due to the increase in the usage of the pump power consumption as flow rate increases also the pump power consumption, which causes the overall efficiency to decrease. It can be seen that efficiency is at a peak at an outside temperature of $0{ }^{\circ} \mathrm{C}$ with a flow rate of $7 \mathrm{LPM}$ flow rate, which is almost $0.00075{ }^{\circ} \mathrm{C} / \mathrm{s} / \mathrm{W}$.

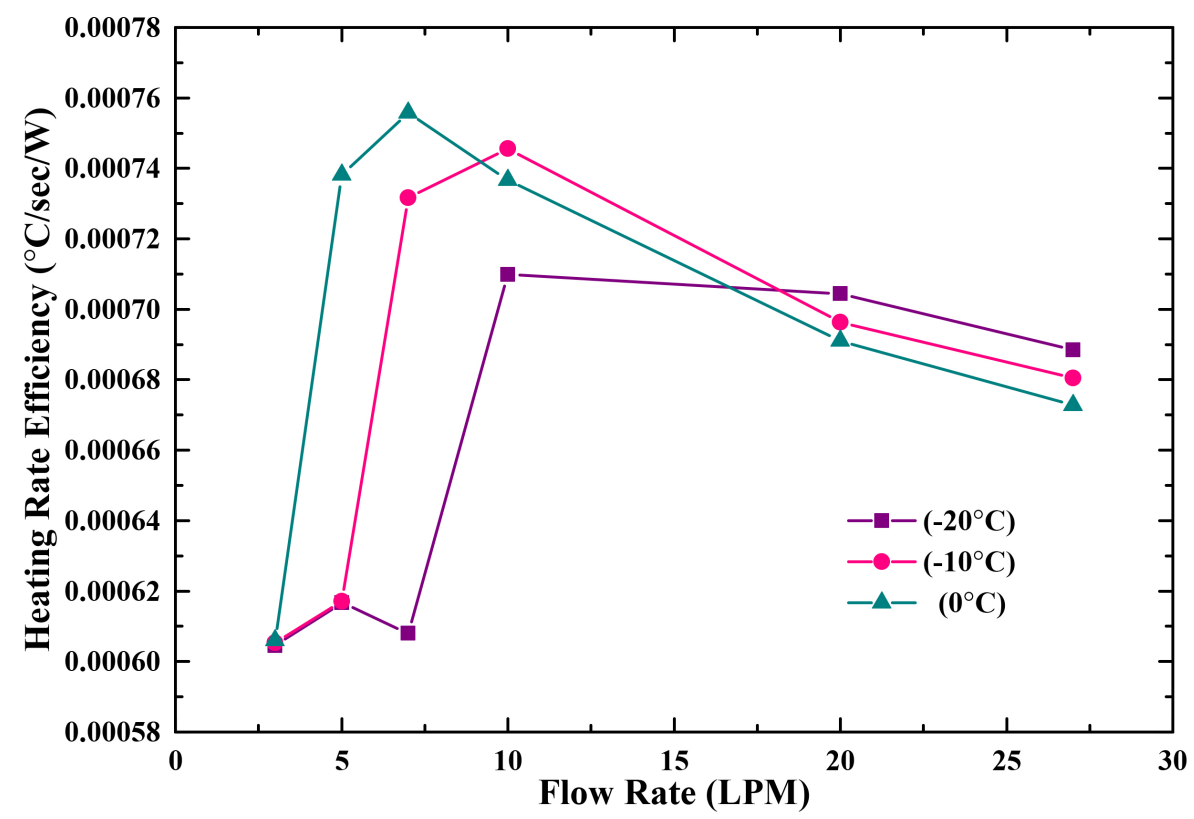

Figure 15. System overall efficiency with heater capacity: 2 kW.

On the other hand, Figure 16 describes the efficiency of the battery thermal management system in a series configuration versus flow rate. Variations of three different ambient temperatures are shown. The $4 \mathrm{~kW}$ capacity of the induction heater was considered for this experiment. All ambient temperature fluctuations Show an irregular pattern, including an increase and decrease up to 20 LPM; after that, output decrease, followed by 27 LPM at the same pace. However, the efficiency is maximum at $0{ }^{\circ} \mathrm{C}$ ambient temperature due to less power consumption than other ambient temperatures. It can be depicted that with a flow rate $3 \mathrm{LPM}$ at an outside temperature of $-10^{\circ} \mathrm{C}$, the efficiency is lowest, and, with a flow rate $27 \mathrm{LPM}$, the efficiency on all three outside temperatures is nearly the same. 


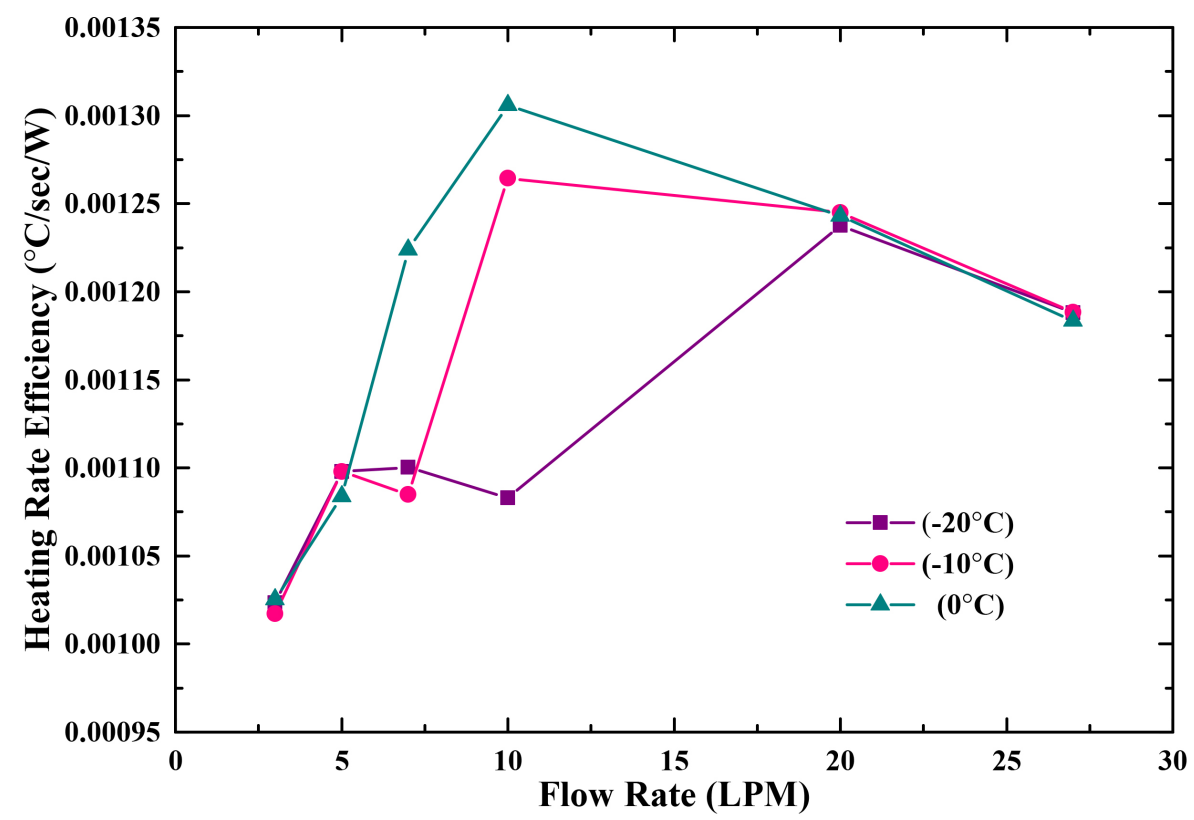

Figure 16. System overall efficiency with heater capacity: $4 \mathrm{~kW}$.

Finally, Figure 17 refers to the efficiency in terms of flow rate for the battery thermal management system. Variations of three different ambient temperatures are shown. The $6 \mathrm{~kW}$ capacity of the induction heater was considered for this experiment. All variations in the ambient temperature show a gradual trend with the same pace up to 10 LPM, and an increase in efficiency up to 20 LPM. In the case of 0 and $-10{ }^{\circ} \mathrm{C}$ outside temperatures, efficiency decreases after $20 \mathrm{LPM}$, while the trend in heating rate efficiency with flow rate at an outside temperature of $-20{ }^{\circ} \mathrm{C}$ is opposite to the trends at -10 and $0{ }^{\circ} \mathrm{C}$. One can see that there is a significant efficiency increase from 10 to $20 \mathrm{LPM}$; efficiency is maximum at $0{ }^{\circ} \mathrm{C}$ ambient temperature due to lower power consumption relative to other ambient temperatures. It reveals that, with a flow rate of $3 \mathrm{LPM}$ at ambient temperature $0{ }^{\circ} \mathrm{C}$, the efficiency is lowest, while, with a flow rate of 20 LPM at the same outside temperature, it is the maximum.

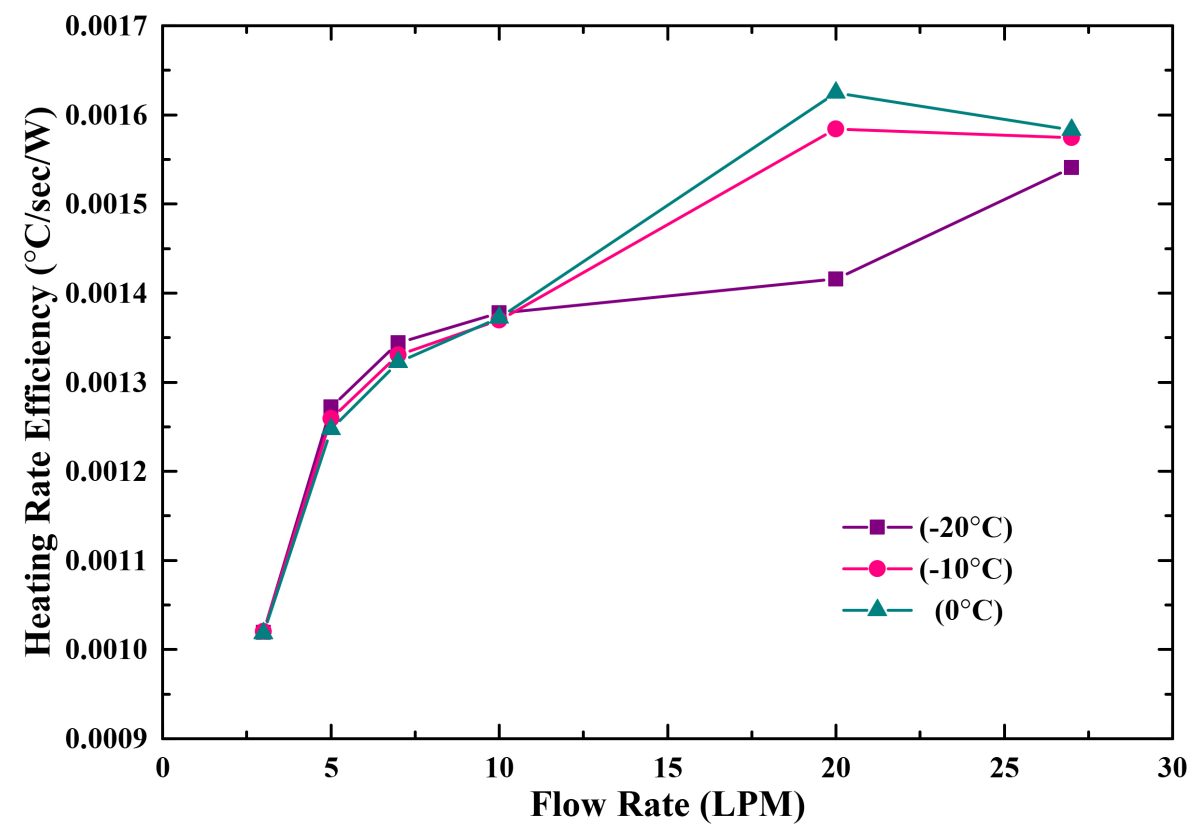

Figure 17. System overall efficiency with heater capacity: $6 \mathrm{~kW}$. 


\subsection{Comparison of Simulation and Experimental Results}

To evaluate the validity of the simulation results with experimental data, a battery pack was tested on a vehicle to match the preciseness of the proposed system, and the findings are demonstrated in Figure 18. The flow rate of $10 \mathrm{LPM}$, heater power of $2 \mathrm{~kW}$, and the ambient temperatures of $-20,-10$, and $0{ }^{\circ} \mathrm{C}$, respectively, were considered as test conditions. The results indicate that the heat transfer coefficient for experimental and simulation analysis was 0.026882 and $0.026816^{\circ} \mathrm{C} / \mathrm{s}$, respectively. The outcomes are almost the same and demonstrate the similarity of the proposed model.

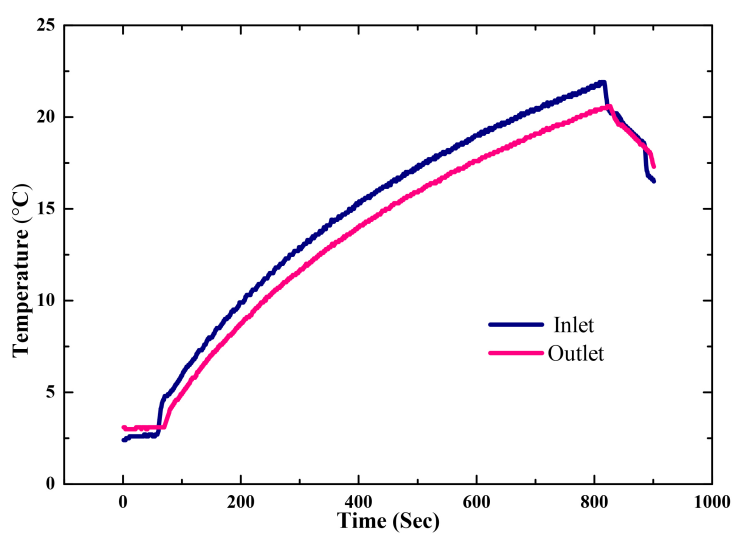

(a) Experimental $\left(0.026882^{\circ} \mathrm{C} / \mathrm{s}\right)$.

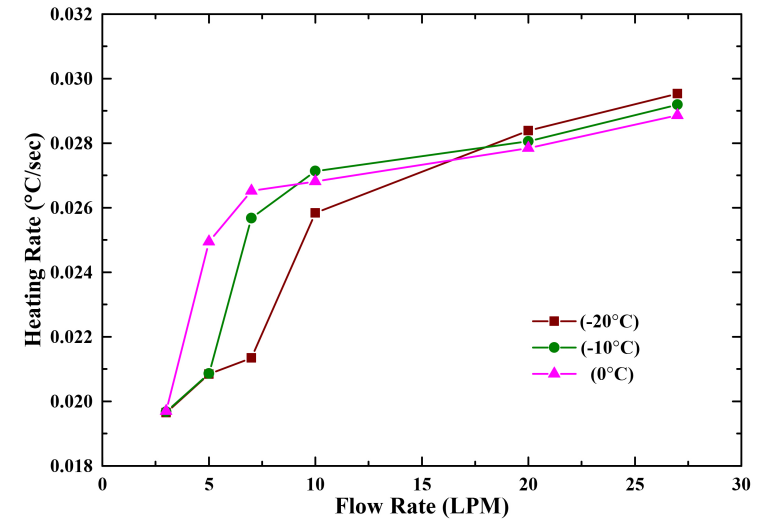

(b) Simulation $\left(0.026816^{\circ} \mathrm{C} / \mathrm{s}\right)$.

Figure 18. Comparison of battery heating rate experimental and simulation results.

\section{Conclusions}

At low temperatures, the lithium-ion battery faces reduced power efficiency and deterioration. Poor performance at low temperatures would hamper the deployment of EVs significantly. Therefore, preheating the ambient temperature to normal range and optimizing the efficiency of the lithium-ion batteries is essential in the cold climate for an EVs battery thermal management system (BTMS). A BTMS by using an induction heater with a single-phase indirect liquid heating system is proposed in this paper. To evaluate the proposed system efficiency, various operating parameters are used to consider how battery pack thermal performance can be achieved in the optimal operating temperature range.

The research investigated the systems heating efficiency under various cold weather conditions by using heating powers of 2, 4, and $6 \mathrm{~kW}$. The performance of the system slightly improves with the rise in flow rate and heating power. The heat transfer rate was maximum with $6 \mathrm{~kW}$ heater capacity at 27 LPM, which indicates the boost in heating rate and the influence of induction heater capacity throughout. On the one hand, to consider the optimal conditions with each capacity of an induction heater under subzero temperature, an equation is used. The heater and pump power consumption are also considered for the determination of optimal flow rate conditions. The optimal flow rate with $2 \mathrm{~kW}$ of heater capacity at $0{ }^{\circ} \mathrm{C}$ is $7 \mathrm{LPM}$, with $4 \mathrm{~kW}$ at $-10{ }^{\circ} \mathrm{C}$ is $10 \mathrm{LPM}$, and finally with $6 \mathrm{~kW}$ at $-20^{\circ} \mathrm{C}$ is 27 LPM; to develop the battery heating system, it is vital to know that.

The BTMS provides an appropriate operating temperature for battery packs and thus ensures high usage performance and long cycle life. Furthermore, to prevent leakage, a liquid heating system requires careful seal design and operation. Besides, using an induction heater, and by adjusting the working fluid flow rate, the reliability, safety, and performance of the electric vehicle may be improved. From a manufacturing viewpoint, a $64-\mathrm{kWh}$ capacity battery pack coupled with $6 \mathrm{~kW}$ of heating power and a flow rate of $27 \mathrm{LPM}$ at outside temperature conditions of $0,-10$, and $-20{ }^{\circ} \mathrm{C}$ is recommended. The proposed BTMS could be a practical approach and help design or analyze the various battery electric vehicle thermal management systems in the future. 
Author Contributions: Conceptualization, G.S.K., and Y.C.P.; methodology, G.S.K., and W.R.; Software, W.R., G.S.K., and Y.C.P.; Validation, W.R., G.S.K., and Y.C.P.; formal analysis, W.R., and G.S.K.; investigation, G.S.K.; resources, Y.C.P.; data curation G.S.K. and W.R.; Writing-original draft preparation, W.R.; writing-review and editing, W.R., and G.S.K.; Supervision, Y.C.P.; funding acquisition, Y.C.P.; and project administration, Y.C.P. All authors have read and agreed to the published version of the manuscript.

Funding: The technology innovation program supported this work (No. 20182020109700, development of a hybrid cooling system for refrigeration truck with an ejector) funded by the Ministry of Trade, Industry and Energy (MOTIE, Korea) and by the National Research Foundation of Korea (No. 2020R1A2C1011871).

Conflicts of Interest: There is no conflict of interest between the authors.

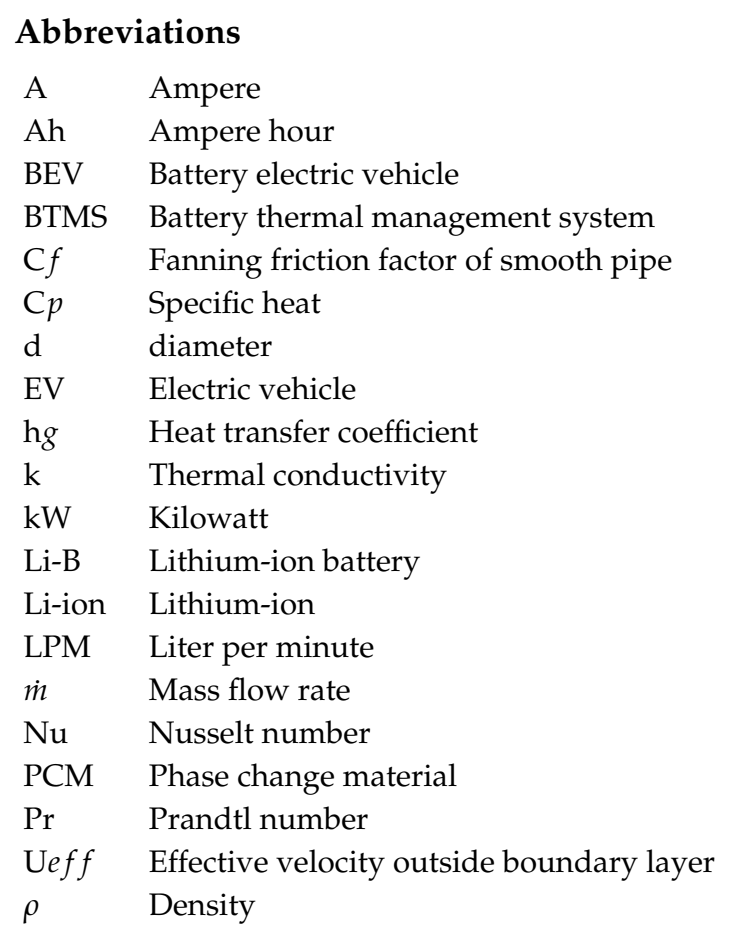

\section{References}

1. BP. BP Energy Outlook 2019 Edition. 2019. Available online: https://www.bp.com/content/dam/bp/ business-sites/en/global/corporate/pdfs/energy-economics/energy-outlook/bp-energy-outlook-2019.pdf (accessed on 21 September 2020).

2. Worwood, D.; Kellner, Q.; Wojtala, M.; Widanage, W.; McGlen, R.; Greenwood, D.; Marco, J. A new approach to the internal thermal management of cylindrical battery cells for automotive applications. J. Power Sources 2017, 346, 151-166. [CrossRef]

3. Khan, P.W.; Byun, Y.C. Smart Contract Centric Inference Engine For Intelligent Electric Vehicle Transportation System. Sensors 2020, 20, 4252. [CrossRef] [PubMed]

4. Budde-Meiwes, H.; Drillkens, J.; Lunz, B.; Muennix, J.; Rothgang, S.; Kowal, J.; Sauer, D.U. A review of current automotive battery technology and future prospects. Proc. Inst. Mech. Eng. Part D J. Automob. Eng. 2013, 227, 761-776. [CrossRef]

5. Gandoman, F.H.; Jaguemont, J.; Goutam, S.; Gopalakrishnan, R.; Firouz, Y.; Kalogiannis, T.; Omar, N.; Mierlo, J.V. Concept of reliability and safety assessment of lithium-ion batteries in electric vehicles: Basics, progress, and challenges. Appl. Energy 2019, 251, 113343. [CrossRef]

6. Mohammed, A.H.; Esmaeeli, R.; Aliniagerdroudbari, H.; Alhadri, M.; Hashemi, S.R.; Nadkarni, G.; Farhad, $\mathrm{S}$. Dual-purpose cooling plate for thermal management of prismatic lithium-ion batteries during normal operation and thermal runaway. Appl. Therm. Eng. 2019, 160, 114106. [CrossRef]

7. Lu, L.; Han, X.; Li, J.; Hua, J.; Ouyang, M. A review on the key issues for lithium-ion battery management in electric vehicles. J. Power Sources 2013, 226, 272-288. [CrossRef] 
8. Zhao, R.; Zhang, S.; Liu, J.; Gu, J. A review of thermal performance improving methods of lithium ion battery: Electrode modification and thermal management system. J. Power Sources 2015, 299, 557-577. [CrossRef]

9. Bandhauer, T.M.; Garimella, S.; Fuller, T.F. A Critical Review of Thermal Issues in Lithium-Ion Batteries. J. Electrochem. Soc. 2011, 158, R1. [CrossRef]

10. Wang, Q.; Jiang, B.; Xue, Q.; Sun, H.; Li, B.; Zou, H.; Yan, Y. Experimental investigation on EV battery cooling and heating by heat pipes. Appl. Therm. Eng. 2015, 88, 54-60. [CrossRef]

11. Pesaran, A.; Keyser, M.; Kim, G.; Santhanagopalan, S.; Smith, K. Tools for Designing Thermal Management of Batteries in Electric Drive Vehicles (Presentation); Technical Report; National Renewable Energy Lab. (NREL): Golden, CO, USA, 2013.

12. Saw, L.H.; Yew, M.C.; Yew, M.K.; Chong, W.T. Numerical analyses on aluminum foams cooling plate for lithium-ion batteries. Energy Procedia 2017, 105, 4751-4756. [CrossRef]

13. Zhang, S.; Xu, K.; Jow, T. The low temperature performance of Li-ion batteries. J. Power Sources 2003, 115, 137-140. [CrossRef]

14. Lei, Z.; Zhang, Y.; Lei, X. Improving temperature uniformity of a lithium-ion battery by intermittent heating method in cold climate. Int. J. Heat Mass Transf. 2018, 121, 275-281. [CrossRef]

15. Ladrech, F. Battery thermal management for HEV \& EV-Technology overview. In Proceedings of the Automotive Summit, Brussels, Belgium, 10 November 2010.

16. Pesaran, A.A. Battery thermal models for hybrid vehicle simulations. J. Power Sources 2002, 110, 377-382. [CrossRef]

17. Sato, N. Thermal behavior analysis of lithium-ion batteries for electric and hybrid vehicles. J. Power Sources 2001, 99, 70-77. [CrossRef]

18. Liao, Z.; Zhang, S.; Li, K.; Zhang, G.; Habetler, T.G. A survey of methods for monitoring and detecting thermal runaway of lithium-ion batteries. J. Power Sources 2019, 436, 226879. [CrossRef]

19. Motloch, C.G.; Christophersen, J.P.; Belt, J.R.; Wright, R.B.; Hunt, G.L.; Sutula, R.A.; Duong, T.; Tartamella, T.J.; Haskins, H.J.; Miller, T.J. High-Power Battery Testing Procedures and Analytical Methodologies for HEVs; SAE Technical Paper Series; SAE International: Warrendale, PA, USA, 2002. [CrossRef]

20. Ramadass, P.; Haran, B.; White, R.; Popov, B.N. Capacity fade of Sony 18,650 cells cycled at elevated temperatures. J. Power Sources 2002, 112, 614-620. [CrossRef]

21. Burow, D.; Sergeeva, K.; Calles, S.; Schorb, K.; Börger, A.; Roth, C.; Heitjans, P. Inhomogeneous degradation of graphite anodes in automotive lithium ion batteries under low-temperature pulse cycling conditions. J. Power Sources 2016, 307, 806-814. [CrossRef]

22. Jaguemont, J.; Boulon, L.; Dube, Y. Characterization and Modeling of a Hybrid-Electric-Vehicle Lithium-Ion Battery Pack at Low Temperatures. IEEE Trans. Veh. Technol. 2016, 65, 1-14. [CrossRef]

23. Jaguemont, J.; Boulon, L.; Venet, P.; Dube, Y.; Sari, A. Low temperature aging tests for lithium-ion batteries. In Proceedings of the 2015 IEEE 24th International Symposium on Industrial Electronics (ISIE), Buzios, Brazil, 3-5 June 2015. [CrossRef]

24. Friesen, A.; Horsthemke, F.; Mönnighoff, X.; Brunklaus, G.; Krafft, R.; Börner, M.; Risthaus, T.; Winter, M.; Schappacher, F.M. Impact of cycling at low temperatures on the safety behavior of 18,650-type lithium ion cells: Combined study of mechanical and thermal abuse testing accompanied by post-mortem analysis. J. Power Sources 2016, 334, 1-11. [CrossRef]

25. Smart, M.; Ratnakumar, B.; Whitcanack, L.; Chin, K.; Surampudi, S.; Croft, H.; Tice, D.; Staniewicz, R. Improved low-temperature performance of lithium-ion cells with quaternary carbonate-based electrolytes. J. Power Sources 2003, 119-121, 349-358. [CrossRef]

26. Gao, F.; Tang, Z. Kinetic behavior of LiFePO4/C cathode material for lithium-ion batteries. Electrochim. Acta 2008, 53, 5071-5075. [CrossRef]

27. Jung, J.; Jeon, Y.; Lee, H.; Kim, Y. Numerical study of the effects of injection-port design on the heating performance of an R134a heat pump with vapor injection used in electric vehicles. Appl. Therm. Eng. 2017, 127, 800-811. [CrossRef]

28. Lin, H.P.; Chua, D.; Salomon, M.; Shiao, H.; Hendrickson, M.; Plichta, E.; Slane, S. Low-temperature behavior of Li-ion cells. Electrochem. Solid State Lett. 2001, 4, A71. [CrossRef]

29. Nagasubramanian, G. Electrical characteristics of $18650 \mathrm{Li}$-ion cells at low temperatures. J. Appl. Electrochem. 2001, 31, 99-104. [CrossRef] 
30. Gogoana, R. Internal Resistance Variances in Lithium-ion Batteries and Implications in Manufacturing. Ph.D. Thesis, Massachusetts Institute of Technology, Cambridge, MA, USA, 2012.

31. Ouyang, M.; Chu, Z.; Lu, L.; Li, J.; Han, X.; Feng, X.; Liu, G. Low temperature aging mechanism identification and lithium deposition in a large format lithium iron phosphate battery for different charge profiles. J. Power Sources 2015, 286, 309-320. [CrossRef]

32. Kim, J.; Oh, J.; Lee, H. Review on battery thermal management system for electric vehicles. Appl. Therm. Eng. 2019, 149, 192-212. [CrossRef]

33. Chen, Y.; Evans, J.W. Heat transfer phenomena in lithium/polymer-electrolyte batteries for electric vehicle application. J. Electrochem. Soc. 1993, 140, 1833. [CrossRef]

34. Pesaran, A.A. Battery thermal management in EV and HEVs: Issues and solutions. Battery Man 2001, 43, 34-49.

35. Khan, M.; Swierczynski, M.; Kær, S. Towards an Ultimate Battery Thermal Management System: A Review. Batteries 2017, 3, 9. [CrossRef]

36. Effat, M.B.; Wu, C.; Ciucci, F. Modeling efforts in the key areas of thermal management and safety of lithium ion battery cells: A mini review. Asia-Pac. J. Chem. Eng. 2016, 11, 399-406. [CrossRef]

37. Saw, L.H.; Ye, Y.; Tay, A.A. Integration issues of lithium-ion battery into electric vehicles battery pack. J. Clean. Prod. 2016, 113, 1032-1045. [CrossRef]

38. Rao, Z.; Wang, S. A review of power battery thermal energy management. Renew. Sustain. Energy Rev. 2011, 15, 4554-4571. [CrossRef]

39. Huo, Y.; Rao, Z. Investigation of phase change material based battery thermal management at cold temperature using lattice Boltzmann method. Energy Convers. Manag. 2017, 133, 204-215. [CrossRef]

40. Zhang, C.; Jin, X.; Li, J. PTC self-heating experiments and thermal modeling of lithium-ion battery pack in electric vehicles. Energies 2017, 10, 572. [CrossRef]

41. Wu, W.; Wang, S.; Wu, W.; Chen, K.; Hong, S.; Lai, Y. A critical review of battery thermal performance and liquid based battery thermal management. Energy Convers. Manag. 2019, 182, 262-281. [CrossRef]

42. Ji, Y.; Wang, C.Y. Heating strategies for Li-ion batteries operated from subzero temperatures. Electrochim. Acta 2013, 107, 664-674. [CrossRef]

43. Luo, Y.; Lang, C.; Luo, B. Investigation into heating system of lithium-ion battery pack in low-temperature environment. J. South China Univ. Technol. (Nat. Sci.) 2016, 44, 100-106.

44. Zhang, J.; Ge, H.; Li, Z.; Ding, Z. Internal heating of lithium-ion batteries using alternating current based on the heat generation model in frequency domain. J. Power Sources 2015, 273, 1030-1037. [CrossRef]

45. Zhu, T.; Min, H.; Yu, Y.; Zhao, Z.; Xu, T.; Chen, Y.; Li, X.; Zhang, C. An Optimized Energy Management Strategy for Preheating Vehicle-Mounted Li-ion Batteries at Subzero Temperatures. Energies 2017, 10, 243. [CrossRef]

46. Zhu, Y.; Fang, Y.; Su, L.; Fei, Y. Experimental study on thermal performance of a pumped two-phase battery thermal management system. Int. J. Energy Res. 2020, 44, 4664-4676. [CrossRef]

47. Giuliano, M.R.; Prasad, A.K.; Advani, S.G. Experimental study of an air-cooled thermal management system for high capacity lithium-titanate batteries. J. Power Sources 2012, 216, 345-352. [CrossRef]

48. Basu, S.; Hariharan, K.S.; Kolake, S.M.; Song, T.; Sohn, D.K.; Yeo, T. Coupled electrochemical thermal modelling of a novel Li-ion battery pack thermal management system. Appl. Energy 2016, 181, 1-13. [CrossRef]

49. Zhang, Z.; Wei, K. Experimental and numerical study of a passive thermal management system using flat heat pipes for lithium-ion batteries. Appl. Therm. Eng. 2020, 166, 114660. [CrossRef]

50. Raza, W.; Ko, G.S.; Park, Y.C. Performance Evaluation of Battery Thermal Management System in Electric Vehicle using Induction Heater (Part 1: Parallel System). Int. J. Air-Cond. Refrig. 2020, 28, 2050003. [CrossRef]

51. Urbanek, P.; Skorek, A.; Zaremba, M. Magnetic flux and temperature analysis in induction heated steel cylinder. IEEE Trans. Magn. 1994, 30, 3328-3330. [CrossRef]

52. Acero, J.; Carretero, C.; Alonso, R.; Burdio, J.M. Quantitative Evaluation of Induction Efficiency in Domestic Induction Heating Applications. IEEE Trans. Magn. 2013, 49, 1382-1389. [CrossRef]

53. Zhang, Z.; Li, W.; Shi, J.; Chen, J. A Study on Electric Vehicle Heat Pump Systems in Cold Climates. Energies 2016, 9, 881. [CrossRef]

54. Song, Z.; Hofmann, H.; Li, J.; Han, X.; Ouyang, M. Optimization for a hybrid energy storage system in electric vehicles using dynamic programing approach. Appl. Energy 2015, 139, 151-162. [CrossRef] 
55. Lv, Y.; Yang, X.; Zhang, G.; Li, X. Experimental research on the effective heating strategies for a phase change material based power battery module. Int. J. Heat Mass Transf. 2019, 128, 392-400. [CrossRef]

56. Jin, L.; Lee, P.; Kong, X.; Fan, Y.; Chou, S. Ultra-thin minichannel LCP for EV battery thermal management. Appl. Energy 2014, 113, 1786-1794. [CrossRef]

57. Daanen, H.A.; van de Vliert, E.; Huang, X. Driving performance in cold, warm, and thermoneutral environments. Appl. Ergon. 2003, 34, 597-602. [CrossRef]

58. Norin, F.; Wyon, D.P. Driver Vigilance-the Effects of Compartment Temperature; Technical Report; SAE Technical Paper: Warrendale, PA, USA, 1992.

Publisher's Note: MDPI stays neutral with regard to jurisdictional claims in published maps and institutional affiliations.

(C) 2020 by the authors. Licensee MDPI, Basel, Switzerland. This article is an open access article distributed under the terms and conditions of the Creative Commons Attribution (CC BY) license (http://creativecommons.org/licenses/by/4.0/). 